\title{
PŘEDBĚŽNÁ ZPRÁVA O VÝSLEDCÍCH ZÁCHRANNÉHO VÝZKUMU V PRAZE 1 - NA KAMPĚ 8/515
}

\author{
DRAHOMÍRA FROLÍKOVÁ - JAN VESELÝ
}

\begin{abstract}
Abstrakt: Při rozsáhlé rekonstrukci objektu čp. 515 v Praze Na Kampé byl proveden záchranný archeologický výzkum v nově podsklepovaných prostorách. Při něm byl zjištěn způsob zakládáni klasicistni dostavby, torza staršich barokních budov, části pecí, koželužské jámy, jámy na vápno, vodovody, kanalizace i studna. Byla odkryta část pilíre románského Juditina mostu a objeveny úseky severovýchodního břehu ostrova Kampa v době pred 18. stoletím.
\end{abstract}

Klíčová slova: Praha - Juditin most - stavby barokní-stavba klasicistní.

\section{Preliminary Report about the Results of Rescue Research in Prague 1, Na Kampě 8/515}

\begin{abstract}
The extensive reconstruction of house no. 515 in Prague, Na Kampé Street involved rescue archaeological research in buildings that were provided with new cellars. The research revealed the foundations of a classicist annexe, remains of baroque buildings, parts of kilns, a tannery pit, a lime pit, water ducts, a sewage system and a well. Part of a pillar of the Romanesque Judith Bridge was unearthed, as well as sections of the north-eastern bank of the Kampa island dating from the period before the 18th century.
\end{abstract}

Key words: Prague - Judith Bridge - baroque buildings - classicist construction.

\section{1. Úvod}

Archeologický výzkum konglomerátu tří budov v severním cípu ostrova Kampa (obr. 1) byl vyvolán záměrem celkové rekonstrukce objektu, jenž měl být při ní téměř celý druhotně podsklepen. Původním podkladem pro rekonstrukci byl stavebně historický průzkum P. Štoncnera (2013), který se pochopitelně soustředil na nadzemní partie. Pro zapracování výsledků následného archeologického výzkumu investor objednal nový stavebně historický průzkum u J. Veselého (2015), s nímž byly objevy základových zdiv průběžně konzultovány z hlediska jejich interpretace a výkladu historických souvislostí. Z toho důvodu v následujícím textu na konstatovaná zjištění archeologického výzkumu bezprostředně následuje vyhodnocení a časové zařazení stavebně historické.

Ostrov Kampa vznik1 v průběhu holocénu z nánosů řeky Vltavy a jeho povrch byl měněn záplavami (jen mezi lety 1118 až 1675 je uváděno 30 povodní, v období od poloviny 16. do konce 17. století 12 velkých povodní; Havrda 2007, 92,94) i lidskou činností. Písemně byl poprvé zmíněn roku 1169 v darovací listině krále Vladislava adresované rádu maltézských rytířu jako bezejmenný ostrov. Od malostranského břehu Vltavy je oddělen ramenem Čertovka, jež ve středověku sloužilo jako mlýnský náhon. Do 16. století byl ostrov využíván jako pole - campus a pastvina, odtud je patrně odvozen i název Kampa.

$\mathrm{Na}$ ostrově jsou dnes torza základů tří pilírư kamenného Juditina mostu z druhé poloviny 12. století (dokončen před 1172; Dragoun 2013, 141). Dva z nich leží pod základy domu čp. 515/III, třetí na sousední parcele východně od nich. Poté, co byl Juditin most stržen povodní v roce 1342, ostrov posloužil rovněž jako základ pro dva z pilířu Karlova mostu z druhé poloviny 14. století. Dům čp. 515/III leží na severním konci ostrova, od jeho hlavní části je opticky oddělen oblouky Karlova mostu. Je nemovitou kulturní památkou, zapsanou v Ústředním seznamu kulturních památek pod rejstř́ikovým číslem 39565/1-886.

\section{Písemné zprávy a historická vyobrazení}

První písemný údaj o domě na severním konci ostrova pochází z roku 1516 a mluví se v něm o domě rybáře Duchka v místě dnešního čp. 515/III. Po velkém požáru Malé Strany a Hradčan roku 1541 byla stavební sut' vyvážena do řeky a posloužila i ke zvýšení úrovně ostrova. 


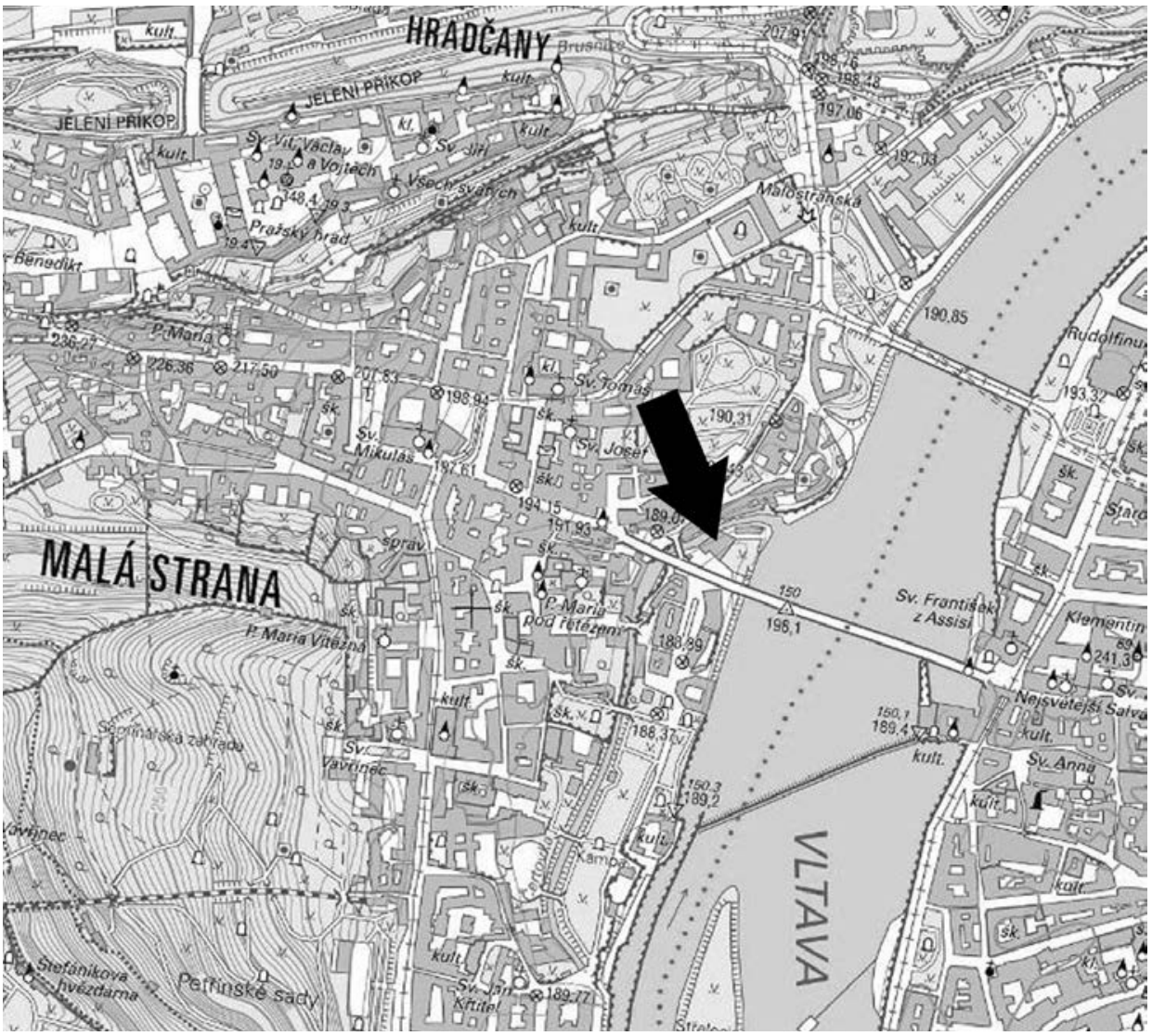

Obr. 1. Praha - Kampa. Poloha domu 8/515 Na Kampě. Podklad - Státní mapa 1 : 10000, ČúZK, Praha.

Abb. 1. Prag - Kampa. Lage von Haus 8/515 Na Kampě. Vorlage - Staatliche Karte 1 : 10000, Tschechisches Amt für Landesvermessung und Kataster, Prag.

Byl tak méně vystaven povodním a započalo se na něm s výstavbou domů a dílenských provozů. Roku 1557 dům přešel do majetku Mikuláše „Prachaře“ a je podle něj nazýván Pulverhof - Prachovna, přičemž výroba prachu v domě je výslovně zakázána. V kupní smlouvě z roku 1601 je uvedeno 15 nájemníků kromě majitele, dům tedy musel být dosti velký. Veduta Roelanta Saveryho zobrazuje v místě domu skrumáž menších staveb, jejímž jádrem je dům s vysokou střechou (obr. 2). Východně od něj stojí stejně vysoká hrázděná věžovitá stavba na šestiúhelném půdorysu. Tzv. Sadelerův prospekt rytý podle předlohy z roku 1606 zachycuje dům s dvojicí věží obklopených dalšími budovami, a rytina Václava Hollara z roku 1636 ukazuje opět dvojici věží (obr. 3), stejně jako dřevořez Kašpara Bechtelera ze Svatovítské katedrály (1620-1630) a rytina Vpád Pasovských Franse Hogenberga z let 1611-1613. Savery nejspíše zobrazil stav před výstavbou oné dvojvěžové budovy (Veselý 2015).

Za švédského obléhání Prahy v roce 1648 byl dům během bojů o most zřejmě vypálen a pobořen, nebot' po roce 1650 se již na žádné vedutě neobjevuje rozměrná stavba s dvojicí věží. Č́ást starších objektů však alespoň ve zdivu určitě zůstala stát. Ovšem již roku 1652 byl obnoven. $\mathrm{V}$ roce 1666 povodeň odplavila část ostrova, jehož břeh byl poté zpevněn roubením a nově navezenou hlínou. Tehdy poprvé je zmiňován v domě čp. 515/III „Waschhaus“, tedy nejspíše prádelna, i když nelze vyloučit ani jiné provozy spojené s máčením. Kresba Volperta van Ouden-Allena z roku 1675 zachycuje na severním cípu ostrova dvě rovnoběžné budovy, které zabírají téměř celou šířku ostrova, tehdy ještě viditelně užšího (obr. 4). Na samém konci 17. století měla 


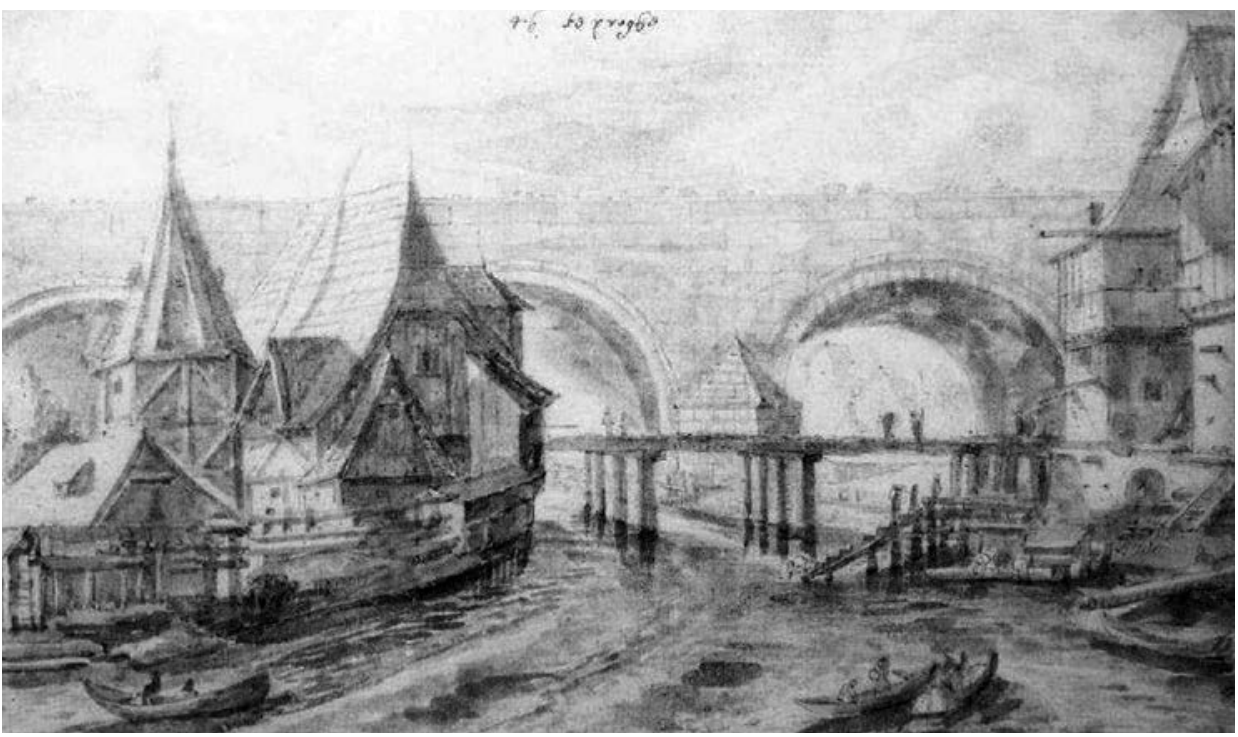

Obr. 2. Praha - Kampa. Roelant Savery, Vltava u Karlova mostu, 1603-1610. Podle Bečková 2000. Abb. 2. Prag - Kampa. Roelant Savery, die Moldau an der Karlsbrücke, 1603-1610. Nach Bečková 2000.

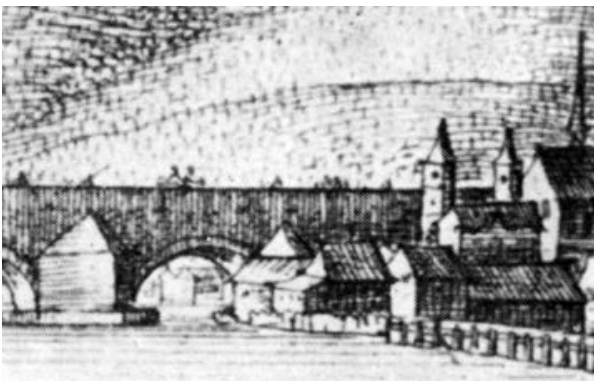

Obr. 3. Praha - Kampa. Václav Holar, Kamenný most v pohledu od severu, 1635, výřez. Podle Hlavsa 1972.

Abb. 3. Prag - Kampa. Václav Holar, Steinbrücke Nordansicht, 1635, Ausschnitt. Nach Hlavsa 1972.

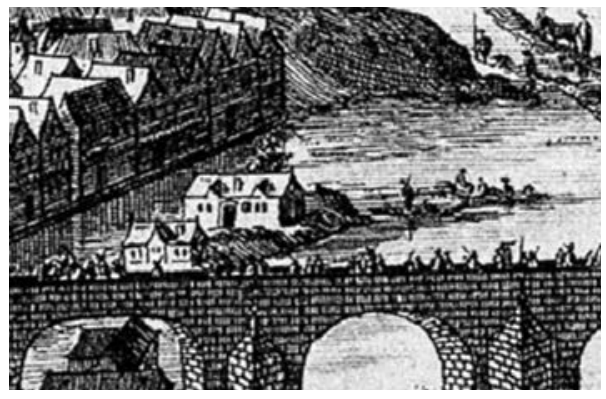

Obr. 4. Praha - Kampa. Volpertus van Ouden-Allen, Pohled na Prahu od jihu, 1675, výřez. Podle Bečková 2000.

Abb. 4. Prag - Kampa. Volpertus van Ouden-Allen, Blick auf Prag von Süden, 1675, Ausschnitt. Nach Bečková 2000.

být podle staroměstské knihy dekretů na starších základech znovu vystavěna samostatně stojící budova severně od nejstaršího jádra domu. Situaci ilustruje plánek z roku 1696 ve zmíněné knize dekretů. Zachycuje již dispozici blížící se dnešní - menší jižní budovy vklíněné do sebe nárožím, takže tvoří L a svírají s větší severní budovou trojúhelníkovitý dvorek (obr. 5). Jižní budovy mají mít funkci prádelny. Severní budova sahá od břehu Čertovky až k břehu Vltavy a má pravoúhle připojené východní křídlo, ostrov byl stále úzký. V roce 1725 je dům popisován jako dvoupodlažní, s prádelnou a palírnou kořalky v př́izemí, tytéž provozy jsou v domě uváděny i v letech 1761 a 1764. Panorama Malé Strany a Hradčan J. J. Dietzlera z let 1730-1735 ukazuje skupinu nejméně čtyř objektů, břeh ostrova je zpevněn dřevěným pažením. Plán J. D. Hubera z roku 1769 zachytil tři patrové budovy orientované ve směru východ-západ a čtvrtou, přízemní lehčí stavbu k nim kolmou ve východní části, o niž byl ostrov rozšiřren. V pozadí hlavních budov se rýsuje střecha propojovací pavlače v patře, rovnoběžné s Čertovkou. Okraje ostrova jsou zpevněny vydřevením. Teprve na Hergetově plánu Prahy z roku 1791 jsou v severním cípu Kampy zakresleny již jen dvě samostatné budovy, jižní tvaru L a obdélná severní, jež dispozičně odpovídají dnešnímu stavu, avšak bez východního křídla. Šířka ostrova už je podobná dnešní. 


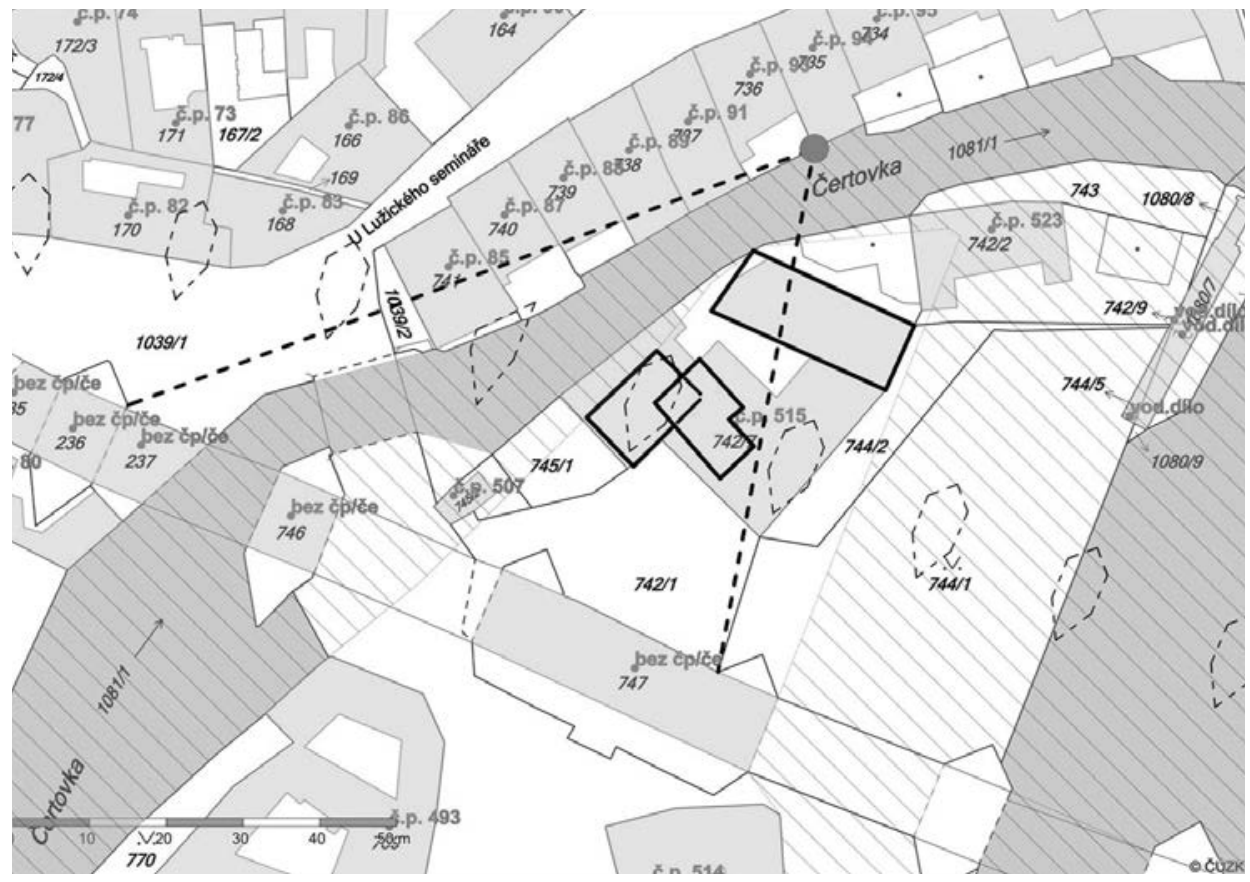

Obr. 5. Praha - Kampa. Srovnání dnešní situace s plánem z knihy dekretů. Do současné katastrální mapy jsou vyneseny obrysy zástavby a rozsah Vltavy a Čertovky dnes (šedě) a v roce 1696 (šrafy). Vyznačeny jsou rovněž předpokládané pilíře Juditina mostu a pozice kreslíře a zorný úhel kresby R. Saveryho z počátku 17. století. Kresba s využitím mapového podkladu ČÚZK Praha J. Veselý.

Abb. 5. Prag - Kampa. Vergleich der heutigen Situation mit einer Planskizze aus dem Dekretbuch. In der aktuellen Katasterkarte sind die Umrisse der Bebauung und die Ausdehnung der Moldau und des Teufelsbachs heute (grau) und für das Jahr 1696 (schraffiert) eingetragen. Ebenfalls hervorgehoben sind die vorausgesetzten Pfeiler der Judithbrücke und die Position des Zeichners sowie der Blickwinkel der Zeichnung von R. Savery vom Anfang des 17. Jahrhunderts. Zeichnung J. Veselý, unter Verwendung einer Kartenvorlage vom Tschechischen Amt für Landesvermessung und Kataster, Prag.

V roce 1800 koupil domy stavitel Michal Brust, který přistavěl východní spojovací křídlo. Současně byly zvýšeny podlahové úrovně přízemí všech částí domu, došlo k vnitřním přestavbám a byl sjednocen vněǰši vzhled v klasicistním slohu. Celý objekt již na dnešním půdorysu je vidět na Jüttnerově plánu Prahy z let 1810-1815. V roce 1815 dům koupili manželé Karel a Marie Pinkasovi. V podstatných rysech se jeho vzhled od té doby nezměnil, docházelo hlavně k vnitřním úpravám. Roku 1906 jej od rodiny Pinkasů vykoupilo město Praha a dům byl rozdělen na malé bytové jednotky, které byly pronajímány (v roce 1926 uvedeno 24 nájemníků). Tento stav zůstal po celé 20 . století. Závažným zásahem do země bylo zřizování koupelen a WC v jednotlivých bytech od 60. let (zpracováno podle Muk-Líbal 1963; Štoncner 2013). V roce 2007 byl dům privatizován formou prodeje Společenství vlastníků, tj. dřívějších nájemníků. Jednotlivé podíly byly postupně vykupovány, v současné době je objekt ve vlastnictví společnosti Artemis Property, s.r. o. Dům je nepodsklepený až na dvě místa: jižní nároží jihozápadního kř́́dla stojí na obvodové zdi dvouprostorového sklepa s valenou klenbou a hliněnou podlahou; v jihovýchodním křídle se sklep nachází pod jeho východní klasicistní př́stavbou, původní vstup měl z jižní strany z (dnešního) exteriéru, stěny jsou křivé, klenba je valená a podlaha rovněž hliněná.

\section{Archeologický výzkum}

Př́ípravě celkové rekonstrukce objektu čp. 515/III předcházel zjištovací výzkum NPÚ územního pracoviště Praha pod vedením J. Podlisky, který měl za cíl zjistit průběh Juditina mostu. Na základě odborného posudku Z. Dragouna (Podliska 2013, 25), který předpokládal piliřr Juditina 
mostu v místech dnešního dvora až severního kř́íla, byla položena sonda 1 v místnosti 18 (obr. 6). Jelikož zde základy pilíře nebyly nalezeny, byly položeny sondy $2-5$ ve stávajících sklepích, z nichž v sondách 2-4 byly základy nalezeny v úrovni 184,60-185,20 m n. m. vzorkováním geologickou sondážní tyčí ve vrstvách pod hladinou spodní vody, pouze v nejvýchodnější části sondy 4 zdivo vystupovalo až do výšky 185,45 m n. m. a mohlo být dokumentováno (Podliska 2013, 19-20). Oba sklepy tedy stojí aspoň zčásti na zbytcích pilířů Juditina mostu.

Projekt přestavby předpokládal podsklepení téměř celého objektu s výjimkou části jihozápadní budovy (obr. 6 - nečíslované místnosti). V roce 2014 byl Archeologický ústav, Praha, v. v. i., osloven, aby zajistil archeologický dohled při hloubení statických sond. Na něj navázal záchranný výzkum v roce 2015.

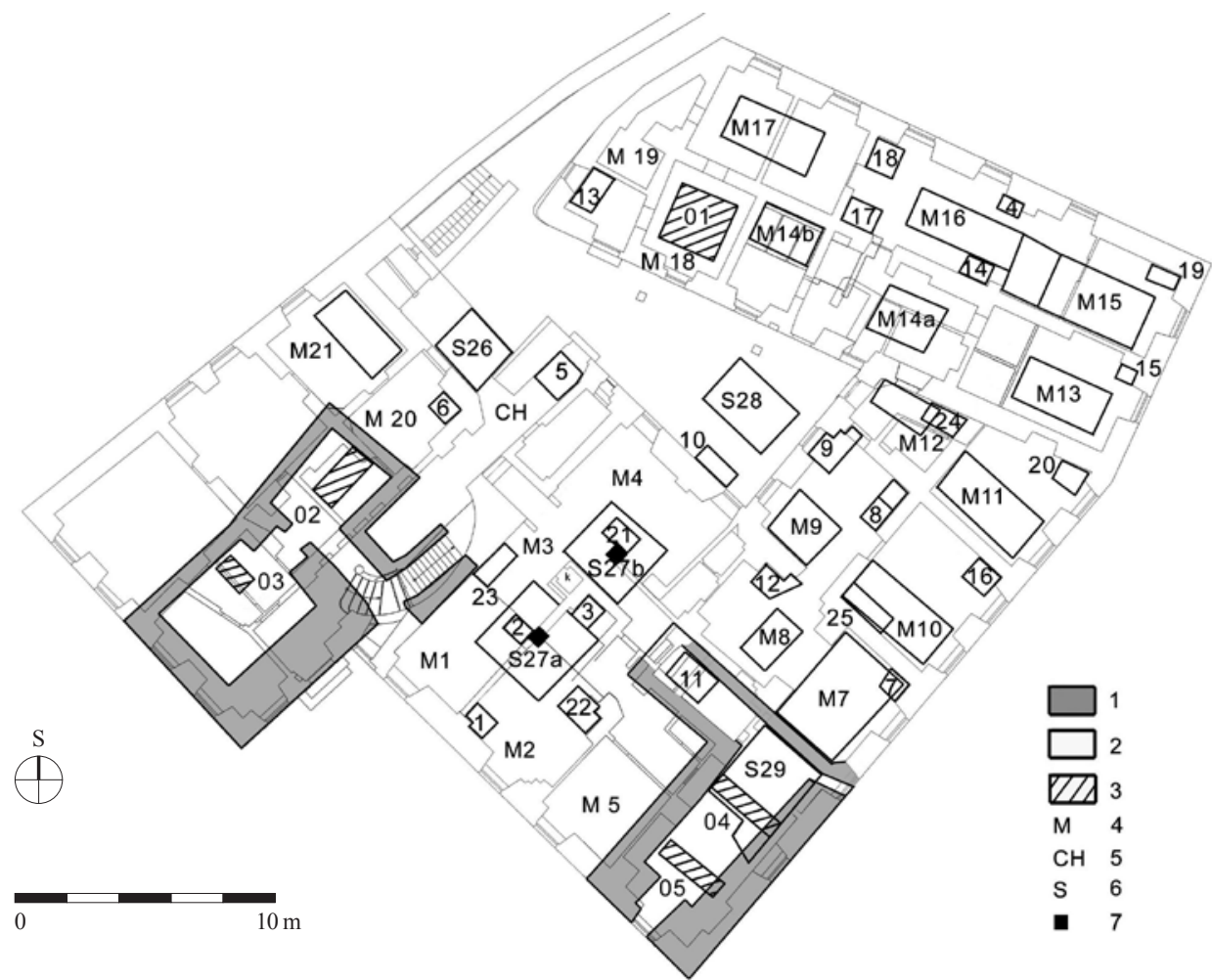

Obr. 6. Praha-Kampa. Rozložení sond v objektu. 1 - sklepy; 2 - statické sondy 1-25 dokumentované ARÚ AV ČR, Praha, v. v. i., v roce 2014; 3 - výzkum NPÚ 2013, sondy 01-05; 4 - číslování místností; 5 - chodba; 6 - sondy $\mathrm{S} 26$-29 z roku 2015; 7 - kamenné pilíře klenuté barokní prádelny.

Abb. 6. Prag - Kampa. Verteilung der Sondierschnitte im Objekt. 1 - Keller; 2 -statische Sondierschnitte 1-25 dokumentiert im Jahr 2014 vom Archäologischen Institut der Akademie der Wissenschaften der Tschechischen Republik; 3 - Grabung des Nationalen Denkmalamts 2013, Sondierschnitte 01-05; 4 - Nummerierung der Räume; 5 - Flur; 6 - Sondierschnitte S 26 -29 aus dem Jahr 2015; 7 - Steinpfeiler des eingewölbten barocken Waschraumes.

\subsection{Zdiva 19.-20. století}

V celém domě se pod úrovní podlah nacházela 20-30 cm silná vrstva úprav z druhé poloviny 20. století sestávajících z vodorovných izolací, rozvodů vnitřních instalací v písčitém zásypu apod., oddělená cementovou vrstvičkou od zásypů stavební sutí, místy slabě prohliněnou. Tyto zásypy obsahovaly zlomky cihel, kamenů, střešních prejzů, kousky malty, ale i úlomky kamnových kachlů a novověké keramiky a pocházejí z doby přestavby na počátku 19. století. Zásypy zakryly vymalované spodní části stěn místností a zvýšily podlahovou úroveň v severním křídle až o $115-130 \mathrm{~cm}$, 
v jižním o 65-70 cm v jeho západní části a o 100 cm v jeho východní části. Zasypané vnitřní omítky ve východním křídle zřejmě pocházely z různých stavebních etap, protože vykazovaly největší výškové rozdíly, mezi 70 až $140 \mathrm{~cm}$.

Klasicistní prř́čky ze smíšeného zdiva stály na klenutých vynášecích pasech položených těsně pod podlahami, vyzdívaných mezi nosné stěny přímo na zásyp fungující jako ztracené bednění. Oproti tomu nově postavené obvodové kamenné zdi byly založeny řádně pod úroveň spodní vody. V místě, kde se napojovalo v ostrém úhlu východní kř́ílo na severní, v sondě M 12 pod základovým zdivem v úrovni $185 \mathrm{~m} \mathrm{n}$. m., těsně nad hladinu spodní vody vyčnívala základová pilota. Dendrologická analýza ukázala, že vzorek pochází z borovice, která byla pokácena na přelomu let 1806-1807 (Kyncl 2015a). Dalších osm pilot bylo objeveno po ukončení výzkumu (za upozornění děkuji stavbyvedoucímu Ing. F. Martínkovi) při podbagrovávání nosného centrálního pilíře vnitřních příček východního křídla pro jeho podchycení mikropiloty a bárkami. Analogicky lze usuzovat, že vnější obvodová mírně zešikmená celokamenná zed' východního křídla byla rovněž založena na pilotách (její základová spára je v úrovních 184,84-185,20 m n. m., pod hladinou spodní vody), s výjimkou úseku nad starším sklepem (v S 29 a části M 7), kde její základy stály na kamenech pilíře Juditina mostu v úrovni až 184,36 m n. m. Zed' mezi místnostmi 7 a 10, a tedy mezi jižním a východním křídlem, přisazená na spáru k východní obvodové zdi, je rovněž celokamenná, avšak založená mělčeji, pouze do naplavenin nad pilířem Juditina mostu: výrazný předzáklad litý do výkopu sahal od $185 \mathrm{~m} \mathrm{n}$. m. na západní straně po 185,20 m n. m. na východní straně, v úrovni těsně pod $186 \mathrm{~m} \mathrm{n}$. m. přecházel do zřetelně šikmé opukové stěny. Těsně pod úrovní podlah, tj. nad 188,50 m n. m., spára mezi zdmi zmizela. Statická sonda S 18 a vybagrování místnosti 17 ukázaly, že střední část obvodové severní zdi severního křídla měla za základ rovněž jen klenutý vynášecí pas. Složité základové poměry v blízkosti Čertovky jsou u obvodových zdí obnažených v sondě M 21 a statické sondě $\mathrm{S} 6$ řešeny, stejně jako ve východním křídle, pomocí vylehčovacích klenutých pasů, které pomáhají svádět zatížení od konstrukcí nadzemních pater do hloubkově založených částí zdiva (úroveň 185,20 m n. m.). Př́čka mezi místnostmi 20 a 21 je přímo založena na klenutém pasu vyzděném mezi nosné stěny.

\subsection{Zdiva 16.-18. století}

Dlaždicové podlahy barokní etapy se místy zachovaly jen v severním křídle, častější byly jejich negativní otisky v podkladové maltě. V místnostech 1-8 v jihovýchodním křídle otisky ukazovaly na podlahu z velkých čtvercových kamenných ploten. Pod ní jsme v sondě M 7 postupně odkryli podlahu z drobných valounů a pod ní další podlahu z nepravidelných vápencových desek, východním směrem vystř́ídaných cihlovými dlaždicemi. Obě tyto podlahy zřejmě ležely vně stojící starší budovy: západní stěnu místnosti 7, původně obvodovou východní zed' budovy, tvořila zed' vyzdívaná do šalování a založená na kamenech pilíře Juditina mostu. V jižní části místnosti se po rozbití maltové podlahy objevilo torzo zdi ze smíšeného zdiva, které nebylo provázáno se žádnou zdí stojící budovy. Bylo založeno poměrně mělce, do vrstev násypů hlíny i stavební suti do úrovně $187 \mathrm{~m} \mathrm{n}$. m. a jeho koruna byla překryta štětováním z hrubých valounů, svažujícím se východním směrem. Snad mohlo jít o nějaký lehký přístavek starší fáze barokní budovy.

Architektonicky nejzajímavějším a památkově nejcennějším nadzemním stavebním prvkem byl prostor v přizemí, zaklenutý původně devíti poli barokních křížových kleneb se čtveřicí hranolových pískovcových pilíř̊o, osmi zděnými polopiliŕri uprostřed obvodových stěn a čtveřicí čtvrtpilířủ v koutech (místnosti 1-4, chodba). Tento prostor sloužil původně jako prádelna - tomuto účelu odpovídá jak typologicky, tak některými stavebními detaily popsanými níže. Provoz prádelny je v domě navíc doložen písemnými prameny od 17. do 19. století. Jeho západní třetina byla již na počátku 19. století výrazně přestavěna - dvě severozápadní klenební pole byla vybourána a v jejich prostoru bylo zrrízeno velkorysé půloválné klasicistní schodiště. Jeden z polopilírů byl zachycen ve statické sondě S 1; zajímavé je, že jihovýchodním směrem od pilíře základové zdivo nepokračovalo - patrně zde byl otevřený průchod arkádami, stejně jako na jihovýchodní straně prádelny. Třetí a čtvrtý pilír byly při vestavbě schodiště pojaty do nové západní zdi. Ve statické sondě S 23 jsme 
odkryli její základové zdivo - smíšené, v horních partiích zalité velmi kvalitní maltou, zahloubené do naplavenin až pod dnešní hladinu spodní vody, tj. pod 184,55 m n. m. Ze zdi vybíhal v místě paty pilíře nepravidelný výstupek - pravděpodobně pozůstatek upraveného původního základu. Výše v úrovni 188,06 m n. m. začínala dřevem hlazená klasicistní vnitřní omítka.

Na základě jednání investora s orgány státní památkové péče zůstal nakonec rekonstruovaný trojlodní klenutý prostor nepodsklepen a zakonzervována pod podlahami zůstala i složitá situace odhalená statickou sondou $\mathrm{S} 22$ při pilíři původně otevřené jihovýchodní arkády, v níž se objevila superpozice nejméně čtyř zdiv, z nichž nejstarší sahá do úrovně $184,77 \mathrm{~m} \mathrm{n}$. m., tj. čtyři metry pod dnešní povrch. Nejstarší podlahová úroveň zachycená v této sondě se nacházela v úrovni $186,12 \mathrm{~m} \mathrm{n}$. m. a šlo pouze o maltové lože dlažby.

S touto podlahou zřejmě koresponduje dláždění odkryté v sondě M 8. Dlaždice kladené do maltového lože byly nalezeny v úrovni $186,29 \mathrm{~m} \mathrm{n}$. m. pod zásypovým souvrstvím. Tato podlaha sahala až k severní stěně místnosti, jak doložila situace ve statické sondě S 12 , zatímco na jižní a východní straně byla ohraničena cihlovou zdí omítnutou hrubou vápennou omítkou. Pod ní jsme odkryli vrstvu cihlové stavební suti ležící na písčité stavební suti a pod nimi v úrovni 185,17-185,19 m n. m. byla další podlaha z dlaždic kladených kosočtverečně, jež ležely na stejných čtvercových dlaždicích kladených rovnoběžně vůči obvodovým zdem sklepa starší fáze. Tato podlaha by měla zůstat zachována jako součást expozice muzea plánovaného ve sklepních prostorách; vrt do hloubky dalších $47 \mathrm{~cm}$, tedy na úrovni ca 184,60 m n. m., narazil na tvrdý kámen - zjevně pokračování zdiva pilíře Juditina mostu z místnosti 7.

Budování nových suterénních prostor mělo podle projektu zůstat ušetřeno jihozápadní kř́́dlo se sklepem, v němž byly zjištěny zbytky západního pilíře Juditina mostu, zato měl být vybagrován a podsklepen celý prostor lichoběžníkového dvorku. Proto byla plánována trysková injektáž obvodového zdiva budov kolem dvora, a protože podle rekonstrukce podoby mostních pilírư (Podliska 2013, obr. 30) nebylo vyloučeno, že by jeho severní špice sahala až do prostoru severozápadní místnosti tohoto křídla, položili jsme v této místnosti sondu podél její severní zdi. V sousední severovýchodní místnosti byla položena již v roce 2014 statická sonda S 6. V sondě M 21 jsme objevili torzo základu zdi neznámé starší budovy ze smíšeného zdiva. Zed' se nakláněla západním směrem do Čertovky a její horní část byla bud’ ubourána, nebo spadla. Z hlediska širších prostorových souvislostí je důležité, že tato zed' v podstatě plynule navazuje na předpokládaný vnější líc obvodového zdiva nejstaršího dochovaného stavebního objektu severního cípu ostrova - dnešního sklepa, založeného na zbytcích západnějšího pilíře Juditina mostu (obr. 6, 14), ve srovnání s ním je však výrazně slabší.

Nynější západní obvodová zed' z opuky nasedala ve 186,20-186,30 m n. m. (250-260 cm pod úrovní podlahy v roce 2013) na cihlovou klenbu kanalizace, jež však ústila proti proudu Čertovky, a jejím účelem tedy bylo spíše vodu přivádět než odvádět splašky. Vrchol klenby kanálu odpovídá dochované úrovni torza zdi. Obvodové zdi i jihovýchodní prř́čka pocházejí z doby klasicistní přestavby. Statická sonda S 6 v sousední místnosti ukázala klasicistní severovýchodní obvodovou zed's druhotně použitými cihlami s barevnými hladkými vnitřními omítkami. Jihovýchodní zed' nese pod úrovní stávající podlahy ( $189 \mathrm{~m} \mathrm{n}$. m.) vnitřní hladkou omítku se zbytky červené a zelené výmalby až do úrovně $188,30 \mathrm{~m} \mathrm{n}$. m. a je patrně barokního původu z doby po roce 1695 . Její základ rozšśřený v úrovni 188,06 m n. m. o 10 cm nasedal v úrovni 186,40 m n. m. na starší kamennou zed', která se k severozápadu do sondy rozšiřovala o $60 \mathrm{~cm}$ a v úrovni $185,80 \mathrm{~m} \mathrm{n}$. m. se rozšiřovala o dalších $20 \mathrm{~cm}$. Tento její předzáklad končil v úrovni $185 \mathrm{~m} \mathrm{n}$. m. Stáří spodní zdi se archeologicky nedá stanovit, je překryta přemístěnou hlinitou vrstvou s ojedinělými kousky malty, uhlíků a kamínků, avšak bez keramických zlomků. Až v úrovni nad $188 \mathrm{~m} \mathrm{n}$. m. se v písčitohlinité navážce s opukovou drtí objevily tři zlomky džbánu s vnitřní hnědou polevou.

Velmi podobná situace byla objevena ve statické sondě S 5, položené v chodbičce vložené mezi jihozápadní a jihovýchodní křídlo, v jejím vyústění na dvorek. Jihovýchodní zed' ve své horní části (od dlažby ve výšce 189 m do 187,60 m n. m.) ukazuje kamenný vynášecí pas podezděný cihlami, který sedí na základovém zdivu zděném do výkopu, s lícem pokrytým maltou, jež sahá pod hladinu spodní vody v úrovni 185,31 m n. m. Severovýchodní a jihozápadní profil 
pod spletí inženýrských sítí nasedal na zbytek dlaždicové podlahy v maltovém loži v úrovni 187,78 m n. m., porušené betonem zalitým výkopem kanalizačního potrubí. Tato dlažba patřila zjevně k barokní trojlodní prádelně (podlahy 187,73-187,99 m n. m.). Zajímavé je, že líc klasicistní severozápadní zdi nenavazoval na barokní zed', ale předstupoval o $30 \mathrm{~cm}$ směrem do chodby, takže vznikl výklenek o výšce $70-80 \mathrm{~cm}$, zasypaný stavební sutí do úrovně recentních podpodlahových úprav o síle $40-50 \mathrm{~cm}$. Pod úrovní barokní dlažby se ve zdi objevily tři řady kamenných bloků položené na maltové vrstvě v úrovni $187,20 \mathrm{~m} \mathrm{n}$. m., a pod nimi pokračovalo základové zdivo zděné do výkopu, s lícem pokrytým maltou, které ve $186,40 \mathrm{~m} \mathrm{n}$. m. nasedalo na zdivo stejného charakteru, avšak pokračující např́íč chodbou. Jeho základ pokračoval pod hladinu spodní vody v 185,30 m n. m. Zjevně jde o zesílený základ nároží barokní budovy.

$\mathrm{Z}$ vnější strany zdí mezi statickými sondami S 6 a 5 jsme otevřeli sondu S 26, abychom mimo jiné ověřili vztah mezi jihozápadním a jihovýchodním kř́dlem. Zjistili jsme, že severovýchodní obvodová zed’ jihozápadního křídla je přizděna ke zdivu jihovýchodního křídla. Základové spáry jihovýchodního křrídla jsme nedosáhli, v úrovni $185 \mathrm{~m} \mathrm{n}$. m. již prosakovala spodní voda. Zdivo bylo kamenné, lícované, v rozmezí 186,80-187,26 m n. m. byl jeho součástí opukový vynášecí pas, nad nímž bylo porušené cihlovým kanálkem a dalšími mladšími zásahy včetně zazdívky cihlami se značkou Hergetovy cihelny. Od dokumentované úrovně $185 \mathrm{~m}$ až do $187,50 \mathrm{~m}$ n. m. (hranice mnohonásobného přezdění) mělo šikmý líc, upadající o $25 \mathrm{~cm}$. Naproti tomu zdivo předzákladu jihozápadního kř́dla mělo vyhřezlou základovou maltu v hloubce 185,16 m, bylo smíšené a v úrovni 186,58 m n. m., na níž byl založen vynášecí pas, ustupovalo o $15 \mathrm{~cm}$. Další patnácticentimetrový ústupek se nacházel v úrovni 187,80 m n. m.

V rozsahu celého severního kř́idla byly pod úrovní stávajících podlah odkryty až $140 \mathrm{~cm}$ vysoké navážky, které pohřbily zbytky barokních dělicích stěn včetně omítek s nátěry, nik dveřních a okenních otvorů a základů komínových těles. Ve velkém rozsahu se pod navážkami zachovaly cihelné dlažby (místnosti 15 a 18), základy topeništ' (místnosti 16, 17, 19) a v místnosti 19 otisky prvotního dřevěného vřetenového schodiště. Ve statických sondách S 20 , S 24 a v sondě M 12 ve východním kř́ídle byla také odhalena část jižní fasády této stavby, s předzákladem a starší omítkou v úrovni 187,37-187,47 m n. m. a mladší omítkou spolu se vstupním prahem v úrovni 187,83 m n. m.; v mladší omítce se zachovala i parapetní lišta šambrány jednoho okna. Zároveň bylo možné jednoznačně odlišit konstrukce a části zdiva starší od oněch, které vznikly na počátku 19. století při přestavbě, během níž byla silná navážka provedena. Klasicistní konstrukce nebyly totiž v úrovni navážky omítané.

V místnosti 15 se statickou sondou S 19 severního křídla byly objeveny zbytky základového zdiva starší stavby, založené na vodorovně kladených trámech. Jejich otisky v obvodovém zdivu stávající budovy a v objevených základech dovolují rekonstruovat jejich podobu jako obdélníkový rám převázaných dvojic vodorovně kladených trámů. Základové zdivo nevzniklo naráz, ale skládalo se z více bloků stýkajících se na spáru, které se lišily charakterem a hloubkou založení. Jako první zdá se vznikla východní zed' ze smíšeného zdiva litého do výkopu, stavěná do mírného oblouku, se základovou spárou v úrovni 186,17 m n. m. K ní je na spáru přizděná jižní zed' východozápadního průběhu stejného charakteru i hloubky a ze severní strany stejná zed', ale založená jen do 186,80 m n. m., která se obloukem stáčí k jihu a tvoří rovnou západní stěnu. Všechny bloky jsou v horní části přezděny do oblouku, takže spáry mezi nimi jsou překryty a celek tvoří nepravidelný útvar. Ten je výsledkem nejméně dvou mikrofází, nejspíše však pouze technologických. Celek budí dojem, že zdivo vznikalo postupným podezdíváním nějakého již existujícího nadzemního objektu. Uvnitř tohoto útvaru se z úrovně $186,31 \mathrm{~m} \mathrm{n}$. m. zahlubovala kůlová jamka, západně od ní se objevily další čtyři uspořádané ve dvojicích, které se zahlubovaly z úrovně $186,85 \mathrm{~m}$ n. m. a zřejmě s ní souvisely. Jestli a jak s tímto objektem souvisel pás opukových kamenů pojených jílem, patrně základ lehké nadzemní, možná i dřevěné, konstrukce, zachycený v sondě M 14A severního křídla v úrovni 186,15-186,40 m n. m., tedy $150 \mathrm{~cm}$ pod úrovní podlah z konce 18. století, není možné zjistit, ač úrovni tehdejšího povrchu odpovídá. Ostatně drobná zástavba pravděpodobně hospodářských stavení je opakovaně zachycena na vyobrazeních od roku 1610 i zmiňována v písemných pramenech. 


\subsection{Př́rodní prostředí, otopná a výrobni zařizení, vodní hospodářství}

Sondy S 10 a S 28 ověřily, že prostor dvora nebyl v minulosti zastavěn. Pod dnešní dlažbou se nacházelo štětování v úrovních 188,60-188,40 m n. m., klesající k Čertovce. Bylo porušené výkopy pro roury deštové kanalizace z 20 . století. V úrovni $186,47 \mathrm{~m} \mathrm{n}$. m. se objevil zbytek dřevěné roury překryté cihlami a opukou naházenou do výkopu, který vedl severojižním směrem. Pod zásypy stavební sutí a hlínou jsme v hloubce 186,25 až 186,0 m n. m. narazili na povodňovou vrstvu jemného zahliněného písku ležící na vrstvě zahliněného štěrkopísku, která opět ležela na jemném zahliněném povodňovém písku (úroveň povrchu 185,98 až 186,24 m n. m.); tyto náplavové vrstvy byly proraženy výkopem pro zed' východního křídla.

V sondě $S 26$ ve vnějším úhlu mezi chodbou a místností 20 jsme našli recentní roury na odvod deštové vody z okapů umístěné mělce pod dlážděním, pod nimi cihlové klenuté kanálky, které vedly pode zdí barokní budovy i šikmo ze dvorku a původně ústily do kamenného korýtka podloženého místy cihlami a překrytého břidlicovou plotnou, které směřovalo do Čertovky. Pod úrovní těchto „,vodoinstalací“ se v severní polovině sondy objevila čtvrtina kruhového obezdění starší studny; ta byla v době jejich zřizování zrušena, zasypána a její vršek ubourán. Její obezdění z kvalitních cihel kratšího formátu ve vazákové skladbě mělo tloušt'ku $26 \mathrm{~cm}$ a pokračovalo další dva metry do úrovně 185,49 m n. m., kde nasedalo na pečlivě vyskládanou obrubu spodní části studny vyzděnou z cihel kratšího formátu, opět ve vazákové skladbě, avšak v tlouštce 42-49 cm (1,5-1,75 cihly, obr. 7). V této hloubce již výplň studny tvořil vlhký béžový písek s proplástky tmavošedého jílu, který pokračoval hlouběji nejméně o další metr (zjištěno navrtáním pedologickou tyčí). Písek měl zřejmě filtrovat nečistoty vody z Vltavy ve studni.

Nejvíce nových poznatků přinesl výzkum v severním a východním křídle, obě měla být celá podsklepena a zároveň na základě sondáže v roce 2013 nebyl ze strany NPÚ vznesen požadavek na památkovou ochranu. Archeologický výzkum v roce 2015 především objevil původní severní cíp ostrova, pokrytý vrstvičkou zetlelého dřeva, který se svažoval až k hladině spodní vody ve $185,10-185,30 \mathrm{~m} \mathrm{n}$. $\mathrm{m}$. V úrovni $185,70-186,00 \mathrm{~m} \mathrm{n}$. $\mathrm{m}$. se v tehdejším povrchu vyrýsovaly paralelní rýhy (obr. 8), které běžely zhruba po vrstevnici severojižním směrem. Pocházejí pravděpodobně od kol vozů, př́ípadně smyků, jimiž byl vožen náklad od lodí do nitra ostrova.
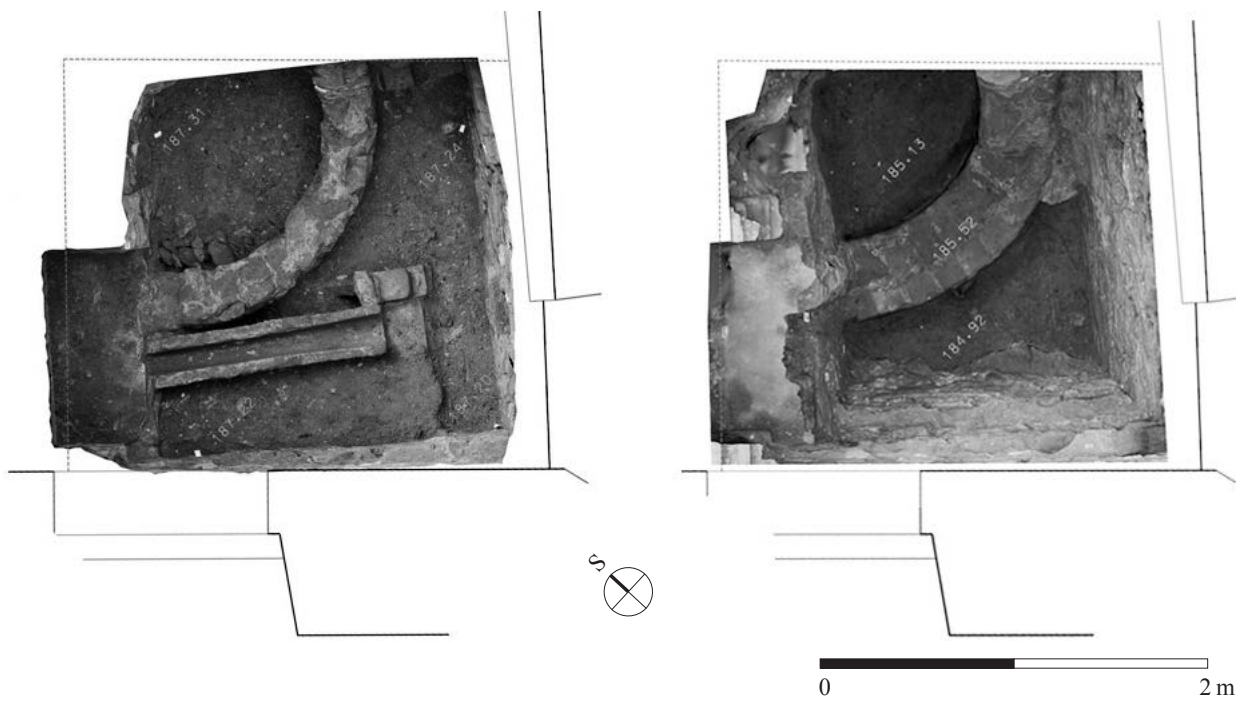

Obr. 7. Praha - Kampa. Sonda 26 - 1. fáze v úrovni 187,20-30 m n. m., 2. fáze okraj studny 185,52 m n. m., vnitřek studny 185,13 m n. m., dno výkopu vně studny 184,92 m n. m. Fotoplán B. Vácha, sestavila D. Frolíková.

Abb. 7. Prag - Kampa. Sondierschnitt 26 - 1. Phase im Höhenniveau 187,20-30 m ü. d. M., 2. Phase Brunnenrand 185,52 m ü. d. M., Brunneninneres 185,13 m ü. d. M., Grabenboden außerhalb des Brunnens 184,92 m ü. d. M. Fotoplan B. Vácha, zusammengestellt von D. Frolíková. 


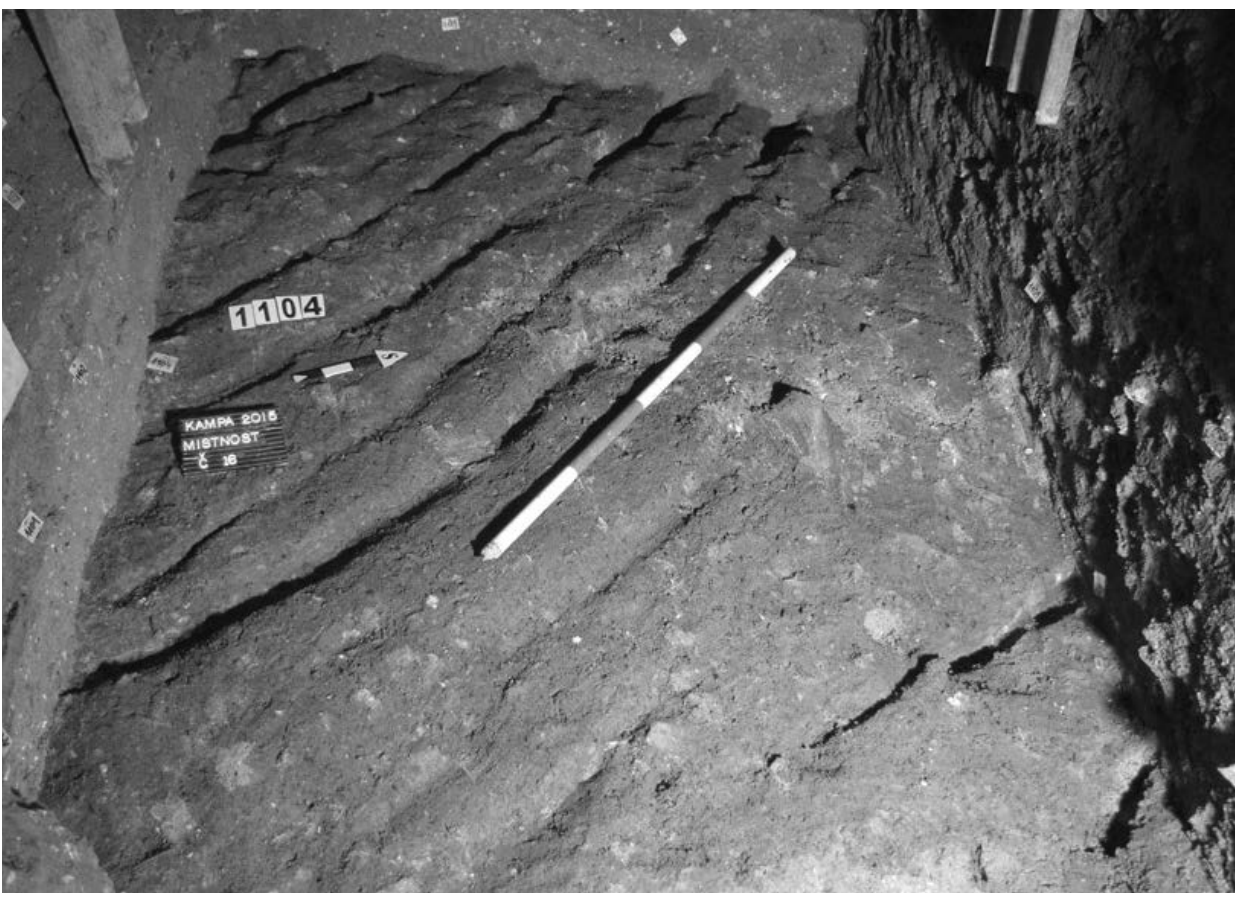

Obr. 8. Praha - Kampa. Rýhy vtlačené do povrchu ostrova na jeho severní špici. Foto M. Smelík.

Abb. 8. Prag - Kampa. An der Nordspitze der Insel in der Erdoberfläche eingepresste Rillen. Foto M. Smelík.

Zbytky dřevěných roštů, které zpevňovaly původní východní okraj ostrova, jsme odkryli v sondě M 13 severního křídla, ve 184,85 m n. m., v úrovni, kam prosakovala spodní voda i v extrémně suchém létě 2015. Z těchto dřev byly odebrány vzorky, které dendrologická laboratoř Ing. T. Kyncla určila jako dub skácený po roce 1569 (Kyncl 2015b).

Zhruba uprostřed jižní části severního křídla v sondě M 14A byla těsně pod úrovní nejmladších barokních podlah nalezena sestava čtyř jam (obr. 9), hlubokých nejméně $100 \mathrm{~cm}$ (v případě, že došlo ke snižování terénu před položením podlah), o průměru také $100 \mathrm{~cm}$, pokud lze usuzovat z největší zjištěné části. Podle V. Gřešáka z Fakulty technologické Univerzity Tomáše Bati ve Zlíněl byla soustava čtyř kádí zakopaných do země uvnitř budovy a propojených rourami nebo kanálky používána $\mathrm{k}$ činění kůží v roztocích tř́ílovin různé koncentrace; to byl tzv. typ „jámy na barvy“, zatímco ve venkovních jámách zvaných „zásypové“ kůže ležely i několik měsíců, zasypané kůrou stromů a zalité vodou. Ostrov Kampa byl pro umístění koželužského provozu vhodným místem, s dostatkem vody kolem a oddělený od hustě obydlené Malé Strany. Ovšem zásypy jam opět neumožnily datování přesnější než interval novověku, pozoruhodná je však absence písemných zmínek o provozování koželužny.

V době některé z přestaveb byl prostor místnosti 17 severního křídla využit ke skladování hašeného vápna $\mathrm{v}$ jámách, $\mathrm{z}$ nichž dvě byly odkryty pod vrstvou propálené hlíny $\mathrm{v}$ úrovni 187,23-187,24 m n. m. v sondě M 17 (obr. 10), ca $40 \mathrm{~cm}$ pod úrovní barokní podlahy. V zásypu jedné z nich byly nalezeny vyhozené poškozené stavební články - tři rozměrné dlaždice a jeden menší blok zdiva, všechny pokryté maltou. S ohledem na polohu jam pocházejí nejspíše z doby výstavby severního křídla na konci 17. století nebo z doby bezprostředně předcházející.

Pod podlahami nejmladší barokní fáze jsme nacházeli vedle zásypů písčitou hlínou se stavební sutí a ojedinělými zlomky novověké keramiky pozůstatky starších otopných zařízení - od

1 Děkujeme za laskavou konzultaci. 


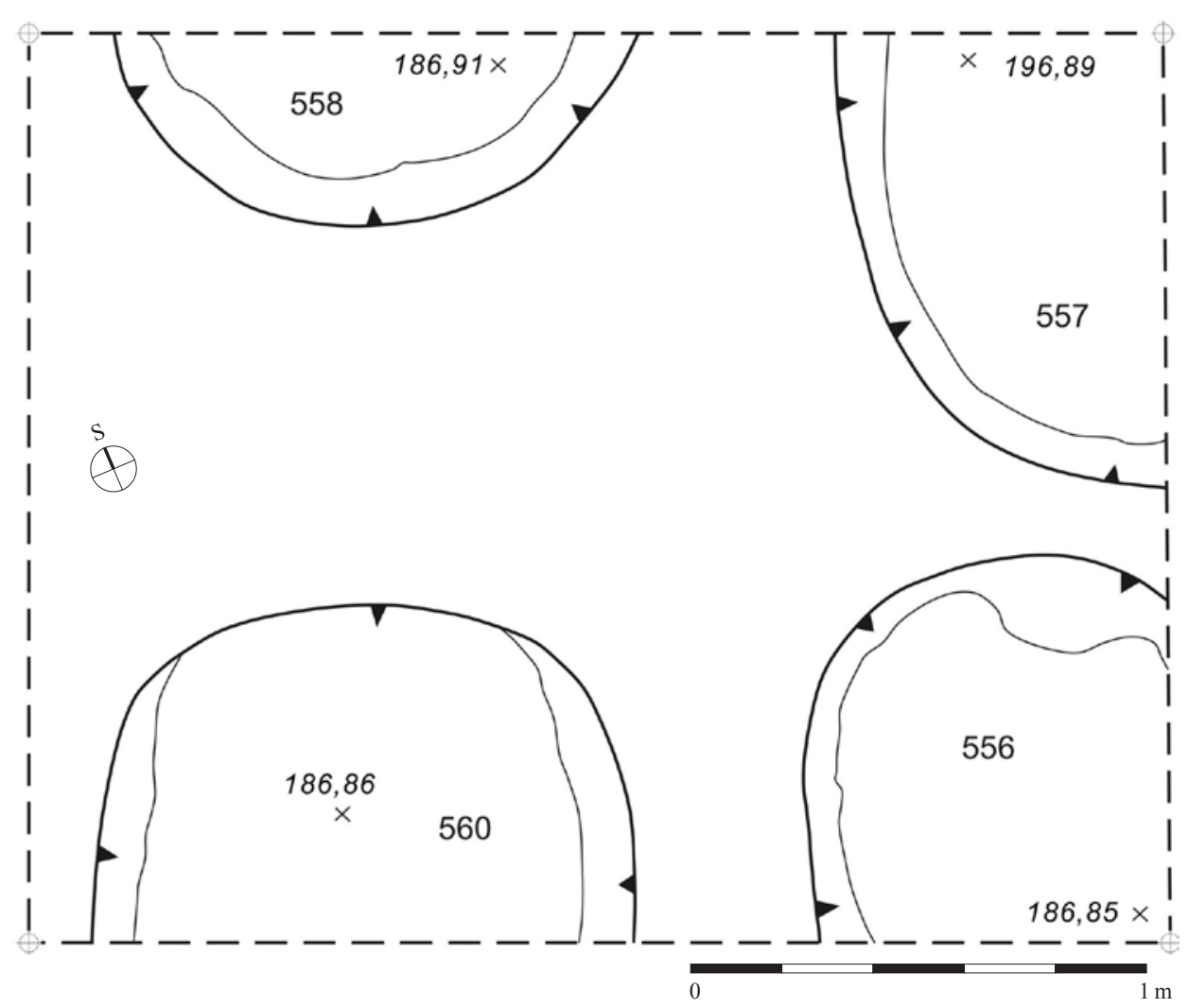

Obr. 9. Praha - Kampa. Jirchářské jámy v severním kř́íde. Kresba J. Kopřivová. Abb. 9. Prag - Kampa. Weißgerbergruben im Nordflügel. Zeichnung J. Kopřivová.

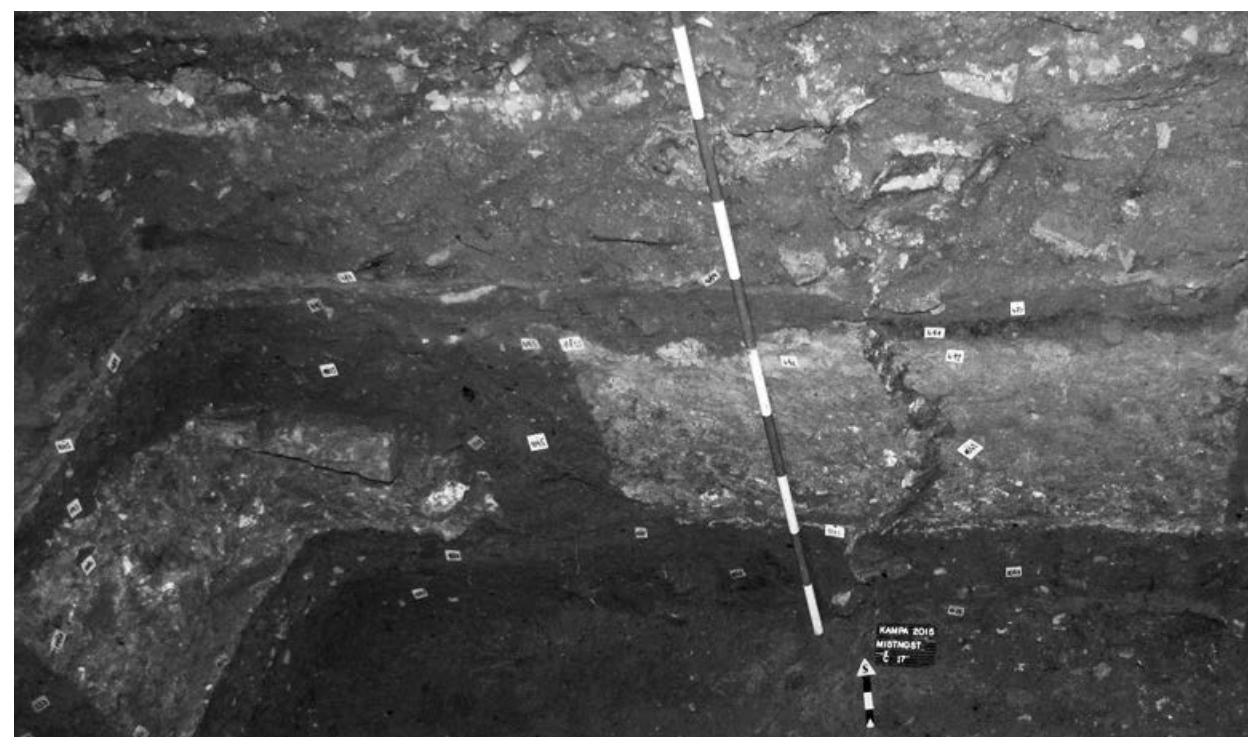

Obr. 10. Praha - Kampa. Jámy na hašené vápno v M 17, řez. Foto M. Smelík.

Abb. 10. Prag - Kampa. Gruben für gelöschten Kalk in Raum M 17, Schnitt. Foto M. Smelík. 
neurčitých zbytků v podobě rozptýlené vrstvy uhlíků v sondě M 15 přes prostou kruhovou pec s podlahou ze čtvercových dlaždic a pláštěm vyzděným z cihel v místnosti 9 až po rozměrný blok staršího zdiva s torzy dvou různě velkých pecí v místnostech 1-4 (místnosti byly očíslovány před vybouráním příček). Tento blok byl narušen již při stavbě klenuté barokní síně - prádelny po roce 1695, kdy do něj byly založeny dva ze čtyř středových nosných pilírů trojlodního prostoru (obr. 11). Tehdy byly částečně prokopané cihelné kobky obou pecí vyplněny propálenou sutí z narušených částí; propálená vrstva stejného charakteru se prostírala i jižně od pece. Torzo jižnější pece prot’ala již statická sonda $\mathrm{S} 3$. Ta zachytila horní líc pláště pece z cihel kladených na plocho v úrovni $187,70 \mathrm{~m} \mathrm{n}$. m., narušený mladšími podlahami, naposledy betonovou dlažbou a rozvody vestavěného sanitárního zařízení; v místech, kde se zachoval, byl povrch cihel silně korodovaný. Sonda při průchodu tělesem pece pod akumulačními vrstvami prořezala mezi úrovněmi ca 187,24 až 187,40 m n. m. klenbu kobky a v úrovni 186,86 m n. m. podestu pece z cihel kladených na plocho. Po začištění celé situace v sondě S 27 v roce 2015 byly nad rubem klenby torza pece identifikovány i zbytky cihelných kanálků odtahu spalin. Podle orientace cihel klenby a umístění odtahu se zdá, že tato pec byla orientována ve směru jihovýchod-severozápad a její

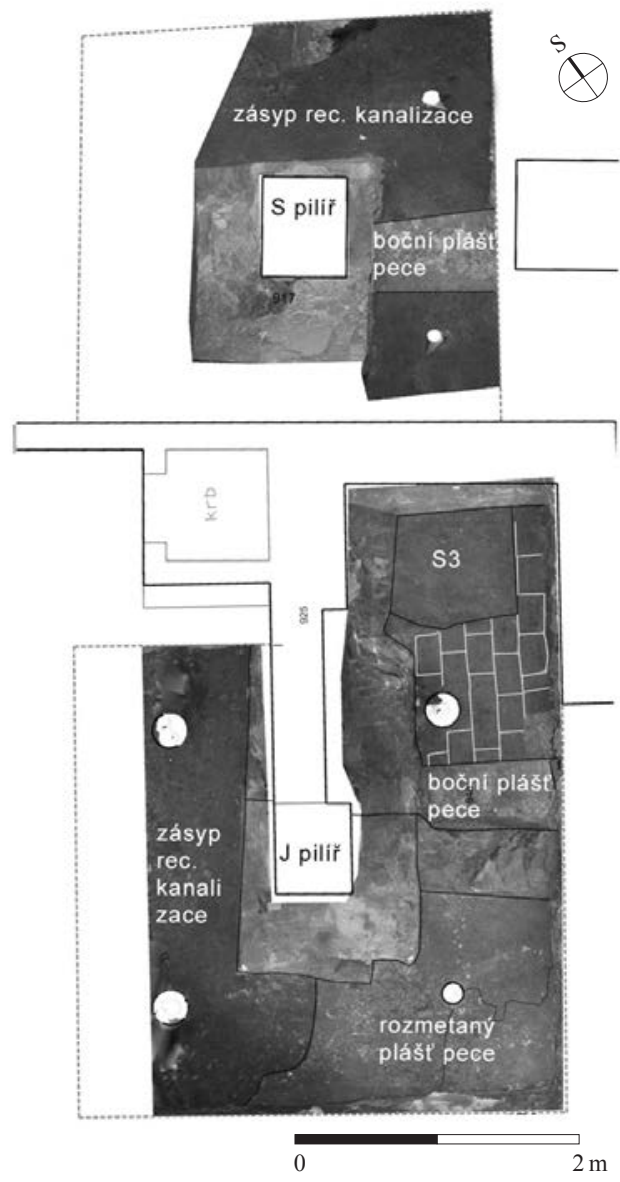

Obr. 11. Praha - Kampa. Situace v sondě 27 - půdorys zbytků barokní pece. Prázdná místa - mikropiloty. Fotoplán B. Vácha, upravila D. Frolíková.

Abb. 11. Prag - Kampa. Situation in Sondierschnitt 27 Grundriss der Überreste des barocken Ofens. Leere Stellen Mikropfähle. Fotoplan B. Vácha, Bearbeitung D. Frolíková. ústí směřovalo na severozápad. Plošný odkryv tohoto technologického zařízení znemožnily jednak zbytky chodbových př́iček, které musely být ponechány kvůli podepření klenby, jednak vrtání mikropilot i skrze pozůstatky pecí a následné obepnutí obou pilíŕů ocelovou konstrukcí převázky. Mezi tyčemi mikropilot se nám podařilo odkrýt pouze útržky cihlových podlah, vnitřní vytápěcí prostor o výšce $30 \mathrm{~cm}$ a části nejméně trojvrstvého pláště pece o síle $50-60 \mathrm{~cm}$ se zbytky kouřovodu. Torzo druhé, severněji položené pece je ještě menší (obr. 12), nebot' její severozápadní část byla zničena výkopem pro recentní kanalizaci, ale můžeme říci, že se tato pec nacházela zhruba ve stejné úrovni jako pec jižní, dle směru kladení cihel její klenby pak soudíme, že byla orientována stejně jako jižnější pec. Výkop byl zastaven těsně pod úrovní dlažby pecí, kladené do maltového lože.

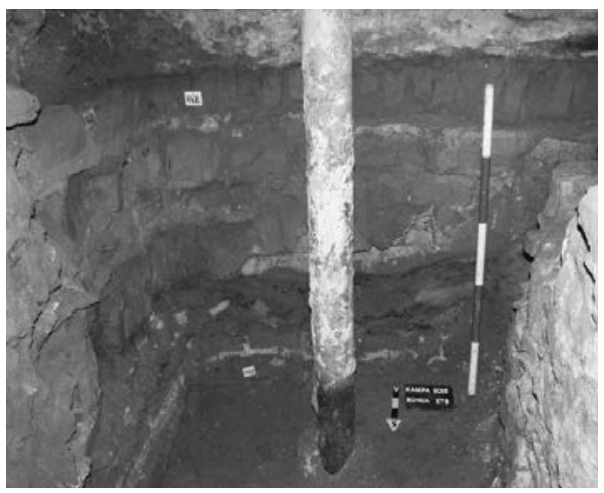

Obr. 12. Praha - Kampa. Řez pecí v severní části sondy. Foto M. Smelík.

Abb. 12. Prag - Kampa. Schnitt durch den Ofen im Nordteil des Sondierschnitts. Foto M. Smelík. 


\subsection{Pilíŕ Juditina mostu}

Architektonickým záměrem projektu bylo ponechat obnažené objevené zdivo východního ze dvou pilírů Juditina mostu nalézajících se na parcele 515/III, proto byla položena sonda S 29 ve sklepě a prokopána celá sousední místnost 7 , v níž se předpokládalo pokračování pilíre. Rozdělením této prostory na tři části jsme získali dva zemní profily. Severní profil zachytil souvrství novověkých navážek, pod nimiž se nad kameny pilíře vytvořilo souvrství naplavenin o zjištěné mocnosti až $80 \mathrm{~cm}$, podle posudku J. Zavřela vzniklé nejméně při dvou záplavách (Zavřel 2015). Povrch těchto naplavenin dosahuje výšky $186,30 \mathrm{~m} \mathrm{n}$. m. (hladina spodní vody zaměřená v květnu 2015 činila 184,84 m n. m.).

Po dokumentaci jižního profilu byl rozebrán útržek staršího zdiva (viz kap. 3.2) a souvrství pod ním včetně naplaveninových vrstviček, které zde sahaly od 185 po $185,80 \mathrm{~m}$. m. Druhá část pilíře byla obnažena ve sklepě, kde vystupoval kamenný blok až na úroveň $185,54 \mathrm{~m} \mathrm{n}$. $\mathrm{m}$. Nalezený zbytek pilíře měl nepravidelné okraje, nebot’ pravidelně opracované bloky kvalitního pískovce, které se používaly na plášt' pilíř̊̊, byly vytrhány a použity pravděpodobně na stavbu Karlova mostu. Jediný kámen, který měl ve viditelné části pravidelně obdélný tvar, délku $100 \mathrm{~cm}$, plochý povrch a mohl by tedy patřit k plášti pilíře, pokračoval pod západní zed’ sklepa. Podle petrografického posudku J. Zavřela se v piliřri vyskytlo 31 kusů středně až hrubě zrnitých velkých rezivých železitých pískovců lomového charakteru, 31 kusů lomových křemenců až jemnozrnných pískovců středně velkých, bělavých, světle šedých, světle okrových i fialově zbarvených, a 21 kusů bělavých až narezlých opukových kamenů. Všechny vyjmenované typy hornin mají ložiska přímo v Praze, železité pískovce pocházejí z Petřína, jemnozrnné křemence až pískovce mají výchozy na Smíchově, v Košiřích, na Novém Městě i na Žižkově, opuka byla lámána na Strahově a Bílé Hoře. „Petrograficky posuzovaná část mostního pilíre v oblasti Kampy zrejmě predstavovala prechodnou partii zdiva se snižujicim se podílem opuk a převažujicím zastoupením kremenců a železitých pískovců." (Zavřel 2015). Tato přechodná partie mezi podvodní a nadvodní částí piliuře se nalézá ve výšce 184,915 až $185,075 \mathrm{~m}$ n. m. Protože po nálezu dlažby sklepa v sondě M 8 už nebyla odkrývána západní polovina pilíŕe nacházející se pod ní, je v současné době v podzemí domu 515/III obnažena asi třetina jádrového zdiva jednoho mostního pilíře v dochované délce $10,30 \mathrm{~m}$ bez rýsujícího se zhlaví (obr. 13).

\section{Rekonstrukce vývoje severního cípu ostrova}

Výzkum na parcele 515/III potvrdil, že na Kampě se nenacházejí vrstvy z raného středověku (Havrda 2007, 91). Nejstarším doloženým pozůstatkem lidské činnosti jsou zbytky pilírů Juditina mostu, jejichž zdivo bylo vytrháno až do úrovně vodní hladiny 184,915 až 185,075 m n. m. Přesné datum jsme naopak získali ze severovýchodního okraje ostrova, z úrovně $184,85 \mathrm{~m} \mathrm{n}$. m., z dřevěných „komor“ zpevňujících břeh, na něž byl použit dub skácený po roce 1569. Dřevo se zachovalo díky tomu, že bylo většinu času pod vodou; lze tedy říci, že hladina Vltavy kolem Kampy se od středověku dodnes nezměnila.

V západní části severního cípu ostrova jsme zachytili obrubu studny $\mathrm{v}$ úrovni 185,40-185,52 m n. m. a k ní příslušející vodorovný povrch terénu z hlinitopísčitých naplavenin do výšky 185,16 m n. m. Studna sice není přesněji datovatelná, avšak ze stratigrafické situace vyplývá, že patří do nejstarší fáze osídlení. Tato úroveň koresponduje s povrchem pokrytým naplaveným dřevem v úrovni 185,10-185,30 m n. m. na nejsevernějším výběžku Kampy. Naplaveniny, které jsme zachytili nad torzem pilíře v sondě $M 7$ a ve sklepní sondě $S 29$, dosahují úrovně 185,80-185,90 m n. m., zahliněná vrstva nad nimi zachycená v sondách S 10 a S 28 sahá po $186,10-186,25 \mathrm{~m}$ n. m., hypoteticky by mohlo jít o půdní horizont pravděpodobně také ze 16. století. Je možné, že zachovaný širší základ nejstarší zdi nalezené v sondě $\mathrm{S} 6$ je dokladem tehdejšího povrchu, na nějž ve 185,80 m n. m. navazovala užší zed' nadzemní.

Uvážíme-li výše uvedené, je pravděpodobné, že nejnižší zjištěná úroveň podlahy uvnitř staveb postavených na parcele, tj. 185,17 $\mathrm{m} \mathrm{n}$. $\mathrm{m}$. v sondě M 8 , pravděpodobně nebude dlážděním obytné místnosti, nýbrž spíše polozapuštěné prostory. 


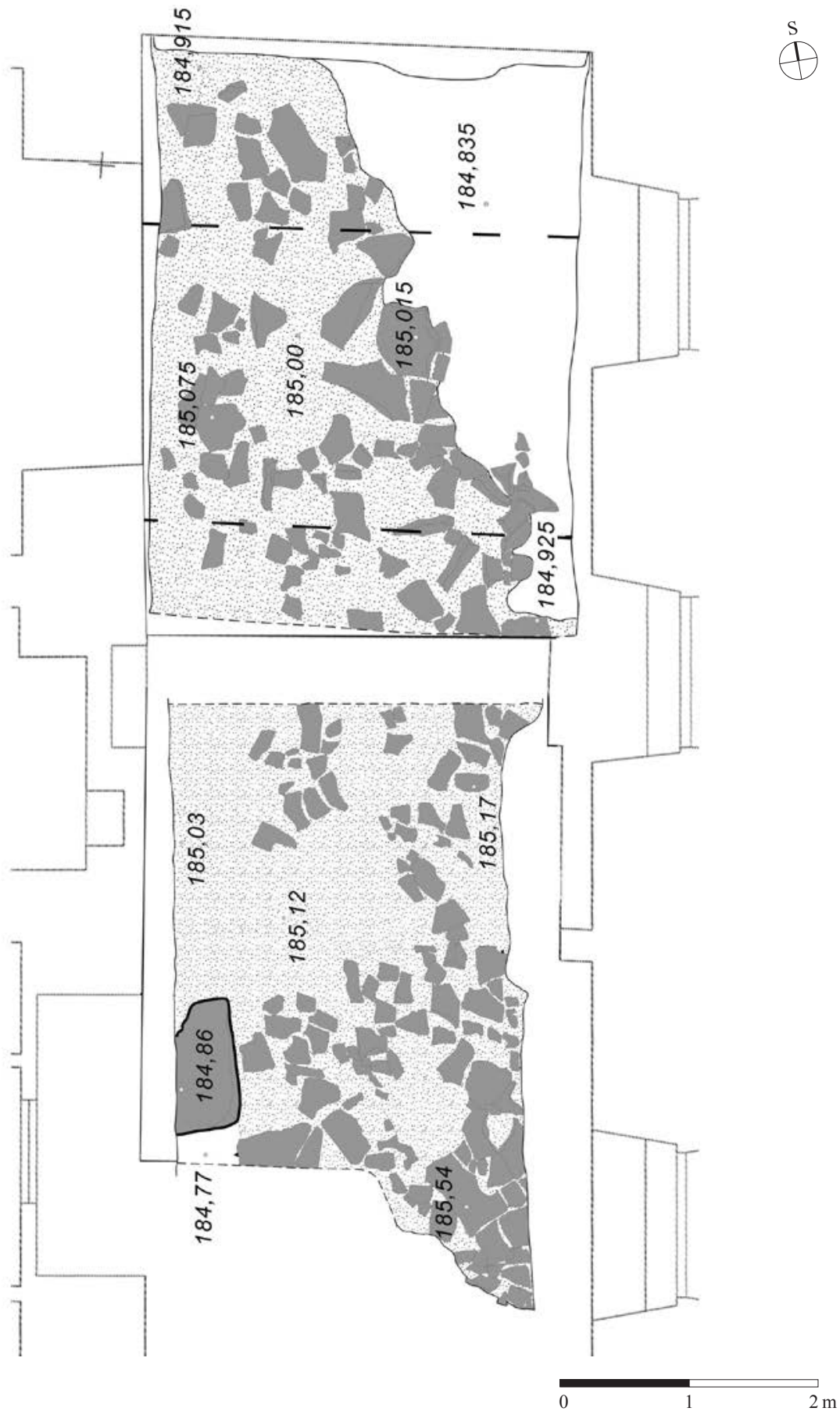

Obr. 13. Praha - Kampa. Pilíř Juditina mostu v místnosti 7 a sondě $S 29$; kameny jádra šedě; zesílený obrys - potenciální kámen pláště; bílá plocha - zdivo zalité spodní vodou; čárkovaně - poloha profilů. Kresba J. Kopřivová.

Abb. 13. Prag - Kampa. Pfeiler der Judithbrücke in Raum 7 und in Sondierschnitt S 29; Steinkern grau; verstärkte Umrisse potenzielle Steine des Mantels; weiße Fläche - mit Grundwasser geflutetes Mauerwerk; gestrichelt - Lage der Schnitte. Zeichnung J. Kopřivová. 


\section{Rekonstrukce stavebního vývoje objektu}

Jak dokládá historická ikonografie místa i množství nálezů fragmentů samostatných drobnějších stavebních objektů v rozsahu celé parcely domu čp. 515/III, byl severní cíp ostrova Kampy vždy intenzivně využíván a stála zde nejpozději od poloviny 16 . století skrumáž více menších staveb. Za nejstarší ze staveb, jejíž významné části byly archeologickým výzkumem a operativním stavebně historickým průzkumem identifikovány, považujeme zděný objekt obdélného půdorysu 8,9 × 12,6 m (dnešní západní sklep), založený na substrukci západního z dvojice piliřů Juditina mostu, na někdejším břehu Čertovky (obr. 14, 15). S poměrně vysokou mírou pravděpodobnosti jej můžeme ztotožnit s jádrem stavby zachycené perokresbou Roelanta Saveryho (obr. 2) někdy mezi lety 1603 a 1610. Jednoduché zděné jádro tohoto domu bylo doplněné nástavbou řady hrázděných nebo dřevěných přístavků a doplňkových objektů, které však nepochybně padly za obět' bojům se Švédy v roce 1648. Do stejného časového horizontu snad můžeme klást též nejstarší úrovně podlah zachycené v sondě M 8 v úrovni 185,17 m n. m., patřící zř̌ejmě částečně zahloubenému prostoru - viz výše.

Záhadnou zůstává mohutná patrová stavba se štíty a dvojicí věží, zachycená prakticky na všech známých vedutách Prahy mezi lety 1606 a 1636. Musela se nacházet v bezprostředním sousedství popsaného staršího domu, nebo vznikla přímo jeho rozšířením. Nejspíše však měla dřevěnou konstrukci a rovněž podlehla při bojích se Švédy. Jak dokládají obě veduty Václava Holara ze 30. let 17. století (obr. 3), stála na vltavském břehu ostrova ještě řada menších staveb, po nichž však žádné jednoznačné stopy zatím nalezeny nebyly, nicméně mohly k nim patřit, např. nejstarší zděný objekt s kůlovými jamkami v sondě M 15 (186,85 m n. m.) a základ pojený hlínou v sondě M 14B (186,32 m n. m.) v severním kř́ídle; obojí však může pocházet i z druhé poloviny 17. století. Předpokládáme, že zástavba byla především hospodářská a souvisela s řemesly využívajícími blízkost vody a odlehlost od souvislé zástavby.

Zástavba na místě dnešního domu byla po roce 1648 rychle obnovena. Můžeme předpokládat, že stavebník v maximální míře využil zděné konstrukce starších staveb, které přestály švédský atak. Na vedutě F. van Ouden-Allena z roku 1675 (obr. 4) je na špici ostrova pod Kamenným mostem zachycena dvojice staveb, z nichž vzdálenější zaujímá polohu dnešního severního kř́illa a má přibližně i jeho proporce (sem můžeme hypoteticky klást jirchářský/koželužský provoz v dnešním severním křídle). Prvním skutečně věrohodným dokladem o rozsahu a podobě zástavby je však až plán z roku 1696, obsažený ve staroměstské knize dekretů (obr. 5), pořízený v souvislosti se znovuvýstavbou severního objektu. Plán obsahuje na vlepeném lístku též část dispozice této stavby. Na základě srovnání dnešní topografie parcely i půdorysů domu s tímto plánem můžeme tvrdit, že zde je zachyceno dodnes stojící jádro severního kř́ídla. Rovněž v jižním a jihozápadním křídle dnešního domu se podařilo identifikovat zbytky konstrukcí staveb obrysově tímto plánem zachycených. Jsou jimi výše popsaný nejstarší obdélný objekt a menší jižní křídlo s pozůstatky pecí. K němu můžeme řadit nálezy ve statických sondách $\mathrm{S} 2,3,5,6,22$ a 23, s předpokládanými podlahovými úrovněmi v rozmezí 186,12 (S 22) až 186,46 m n. m. (S 2, $5,6,12)$, tedy $40-70 \mathrm{~cm}$ pod podestami pecí zachycených sondami S 3 a $27 \mathrm{~B}(186,86 \mathrm{~m} \mathrm{n}$. m.).

Díky dobré zachovalosti situací pod klasicistní navážkou můžeme poměrně spolehlivě rekonstruovat barokní podobu severního kř́ídla domu - původně samostatného patrového objektu zachyceného všemi vedutami od konce 17. do konce 18. století. Stavba sloužila bezpochyby jako nájemní dům s množstvím malých bytů. V přízemí (podlahová úroveň ca 187,60-187,90 m n. m.) byly jednopokojové byty sdružené po dvojicích se společným vstupem a předsíní s dymníkovou kuchyní, uspořádané v podélné dvoutraktové dispozici se vstupy ze severní i z jižní strany. Dispozici patra sice neznáme, ale musela se lišit od př́izemí, nebot' přístup do bytů byl možný pouze z pavlače na jižní straně, navazující na zmíněné schodiště v místnosti 19 . V rámci klasicistní přestavby přibylo druhé patro. Dvoutraktová dispozice byla zopakována, avšak komunikační schéma i vlastní dělení na jednotlivé byty se změnilo. Nejprve bylo zrušeno vnitřní schodiště a pavlače pater byly zpřístupněny lávkami z protějšího křídla, posléze bylo zřízeno i nové interiérové schodiště, ve stř̌edu jižního traktu. 


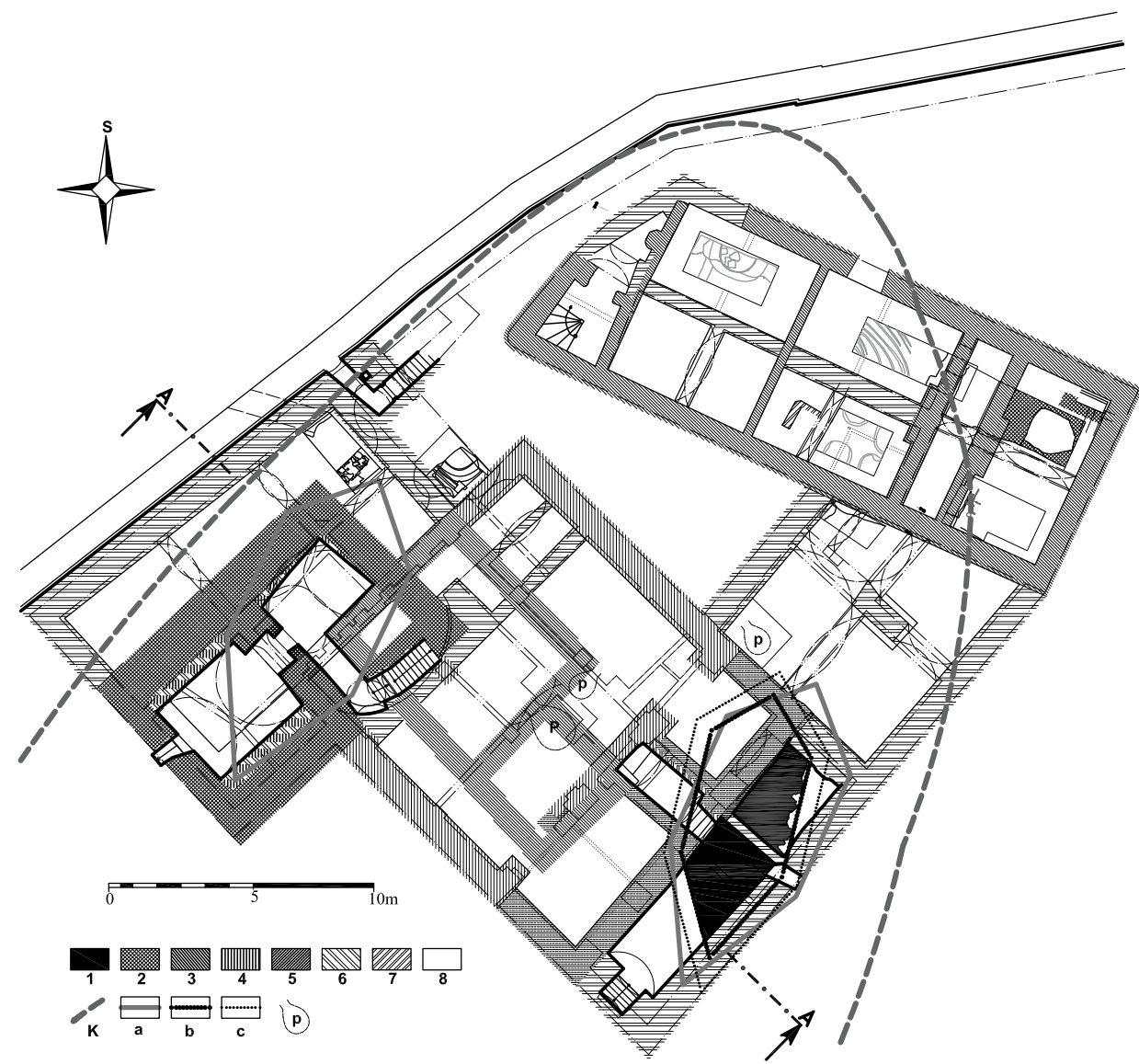

Obr. 14. Praha - Kampa. Analytický půdorys v úrovni suterénu. 1 - zdivo Juditina mostu; 2 - zdivo nejstaršího objektu založeného na západním pilíři Juditina mostu; 3 - zdivo první barokní fáze, před 1695; 4 - zdivo druhé barokní fáze, kolem 1715; 5 - zdivo třetí barokní fáze, kolem 1760; 6 - klasicistní zdivo kolem 1810; 7 - zdivo druhé klasicistní fáze; 8 - mladší zdivo; K - předpokládaný obrys severní špice Kampy na konci 16. století; a - předpokládaná poloha pilírư Juditina mostu (Podliska 2013); b - rekonstrukce polohy jádra pilíře Juditina mostu dle nalezeného zdiva; c - předpokládaný obrys líce pilíře; $\mathbf{p}$ - polohy odkrytých pecí. Na podkladě terénní dokumentace vynesl J. Veselý.

Abb. 14. Prag - Kampa. Analytischer Grundriss im Erdgeschossniveau. 1 - Mauerwerk der Judithbrücke; 2 - Mauerwerk des ältesten, auf dem Westpfeiler der Judithbrücke gegründeten Objektes; 3 - Mauerwerk der ersten barocken Phase, vor 1695; 4 - Mauerwerk der zweiten barocken Phase, um 1715; 5 - Mauerwerk der dritten barocken Phase, um 1760; 6 - klassizistisches Mauerwerk um 1810; 7 - Mauerwerk der zweiten klassizistischen Phase; 8 - jüngeres Mauerwerk; K - angenommener Umriss der Nordspitze von Kampa Ende des 16. Jahrhunderts; a - angenommene Lage der Pfeiler der Judithbrücke (Podliska 2013); b - Rekonstruktion der Lage des Pfeilerkerns der Judithbrücke gemäß dem vorgefundenen Mauerwerk; c - angenommener Umriss der Außenseite des Pfeilers; p - Lage der freigelegten Öfen. Auf Grundlage der Geländedokumentation erstellt von J. Veselý.

Nejspíše na počátku 18. století bylo jižní křídlo domu s prádelnou nově vystavěno na širším půdoryse. V přízemí vznikl velkorysý trojlodní klenutý prostor nové prádelny, otevřený k jihu trojicí oblouků. Ten byl na konci 60 . let rozšířen $\mathrm{k}$ jihu o další trojdílný trakt, opět otevřený do exteriéru širokými oblouky. Pilíře těchto oblouků byly založeny na zdivu prováděném do dřevěného bednění, jak se ukázalo v místnosti M 7. S rozšířením prádelny pak patrně souvisí i valounová dlažba (187,74-188,07 m n. m.) a nevelký blok zdiva, obé nalezené tamtéž. Šlo pravděpodobně o základ nádrže a pochozí plochu pro venkovní část prádelního provozu.

Provoz prádelny zůstal zachován i po celkové klasicistní přestavbě domu M. Brustem po roce 1807 , kdy byl dům rozšířen o východní křídlo a celkově zvýšen o druhé patro. Velký trojlodní prostor byl sice na severozápadě zmenšen o tři pole, na jejichž místě vzniklo nové scho- 


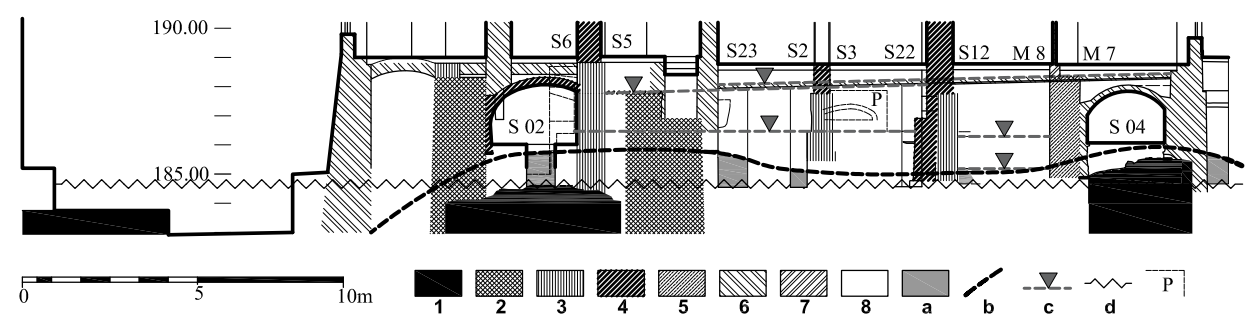

Obr. 15. Praha - Kampa. Analytický př́ičný řez Čertovkou a špicí ostrova Kampy s domem čp. 515. 1 - zdivo Juditina mostu; 2 - zdivo nejstaršího objektu založeného na západním pilíři Juditina mostu; 3 -zdivo první barokní fáze, před 1695; 4 -zdivo druhé barokní fáze, kolem 1715; 5 - zdivo třetí barokní fáze, kolem 1760; 6 - klasicistní zdivo kolem 1810; 7 - zdivo druhé klasicistní fáze; 8 - mladší zdivo; a - jílovitopísčité náplavy, po rozebrání Juditina mostu; b - předpokládaná modelace terénu severní špice Kampy před vznikem zástavby (konec 16. století); c - starší podlahové úrovně zachycené výzkumem; d - průměrná úroveň vltavské hladiny; $P$ - pec. Na podkladě terénní dokumentace vynesl J. Veselý.

Abb. 15. Prag - Kampa. Analytischer Querschnitt durch den Teufelsbach und die Spitze der Insel Kampa mit Haus Nr. 515. 1 - Mauerwerk der Judithbrücke; 2 - Mauerwerk des ältesten, auf dem Westpfeiler der Judithbrücke gegründeten Objektes; 3 - Mauerwerk der ersten barocken Phase, vor 1695; 4 - Mauerwerk der zweiten barocken Phase, um 1715; 5 - Mauerwerk der dritten barocken Phase, um 1760; 6 - klassizistisches Mauerwerk um 1810; 7 - Mauerwerk der zweiten klassizistischen Phase; 8 - jüngeres Mauerwerk; a - lehmige Sandanschwemmungen, nach Zerlegung der Judithbrücke; $b$ - angenommene Modellierung des Geländes der Nordspitze von Kampa vor Entstehung der Bebauung (Ende 16. Jhdt.); c - durch die Grabung festgestelltes, älteres Fußbodenniveau; d - durchschnittlicher Pegelstand der Moldau; P - Ofen. Auf Grundlage der Geländedokumentation erstellt von J. Veselý.

diště a chodba, ale zároveň byl na jihu rozšířen o částečně podsklepený trakt. Je zajímavé, že celkové výrazné navýšení úrovně terénu i podlah se do prádelny promítlo jen částečně a její podlaha zůstala níže, zvýšena pouze přidáním nové jednotné dlažby z rozměrných vápencových desek, spádované od jihu k severu do místnosti 4 (maltové lože 187,88-187,98 m n. m.), odkud vedl zděný odvodňovací kanál ústící kamenným korytem odhaleným v sondě S 26 do opěrné zdi nad Čertovkou.

Kolem poloviny 19. století byla pak prádelna zrušena a velkorysý prostor v prŕzemí byl přeprríčkován a změněn na byty. $V$ té době byla i zde navýšena podlaha násypem, přesto však zůstala oproti jiným částem domu níže.

V pozdější době byly v úrovni přízemí a pod ní prováděny především utilitární technické úpravy, především několikafázové budování a opravy kanalizace a odvodnění, při nichž byla narušena řada substrukcí starší zástavby, dochovaných pod úrovní terénu a podlah. Tyto zásahy způsobily nejednoznačnost interpretace některých situací, odhalených záchranným archeologickým výzkumem.

\section{Závěr}

Archeologický výzkum domu čp. 515/III mírně korigoval polohu byt' jen částečně odkrytého pilíře Juditina mostu pod jihovýchodní částí domu. Zároveň ukázal, že až na jediný vyčnívající kus zůstalo zachováno jen zdivo pod úrovní vodní hladiny a že pravidelně opracované pískovcové kvádry obvodového zdiva byly vytrhány, takže z dochovaného jádra nelze určit rozměry pilíře. Podařilo se určit úroveň 184,915 až $185,075 \mathrm{~m} \mathrm{n}$. m. jako přechodový horizont mezi podvodní a nadvodní částí pilíře díky změně v užitých druzích kamene.

Torza starších zdiv potvrzují zprávy písemných a obrazových pramenů o složitém stavebním vývoji objektu, dovolují však jen hypotetickou rekonstrukci, což vyplývá z rozdílnosti pramenů - archeologický průzkum zachycuje obvykle jen podzemní základové zdivo. Díky výraznému zvýšení podlahové úrovně při přestavbě barokního objektu v klasicistním stylu jsme ovšem mohli podobu nejmladší barokní fáze rekonstruovat dosti podrobně. Př́nosem pro historii objektu je objev založení klasicistního východního křídla na dřevěné piloty, a tím zpřesnění doby jeho stavby z intervalu 1800-1810 na dobu mezi lety 1808 a 1810. Z archeologického hlediska jsou významným př́nosem výzkumu odkrytí severovýchodního okraje ostrova, dendrochronologicky datované zpevnění jeho východního okraje a objev koželužské dílny, z jiných pramenů neznámé. 
Terénní část archeologického výzkumu skončila v srpnu 2015, proto jde pouze o předběžnou zprávu a dílčí závěry, ke kterým jsme došli díky průběžné spolupráci, mohou být po podrobném zpracování terénní dokumentace a nálezů korigovány. Navíc pokračující stavební práce v suterénech stále přinášejí občasné nečekané objevy, které však nelze z časových důvodů zapracovat do tohoto článku.

\section{Prameny a literatura}

BEČKOVÁ, K., 2000: Zmizelá Praha - Hradčany a Malá Strana. Praha: Paseka.

HLAVSA, V., 1972: Praha očima staletí. Praha: Orbis.

DRAGOUN, Z., 2003: Praha 1 - Malá Strana, U Lužického semináře čp. 77/III. In: Dragoun, Zd. a kol., Archeologický výzkum v Praze v letech 1999-2000. Pražský sborník historický 32, 313-314. Praha.

- 2013: Praha 885-1310. Kapitoly o románské a raně gotické architektuře. Praha.

HAVRDA, J., 2007: Kampa - ostrov povodní a navážek. Nástin vývoje na základě archeologických pramenů Kampa - the island of floods and embankments. An outline of its development based on archaeological sources, Archaeologica Pragensia 18, 77-96.

KYNCL, T., 2015: Výzkumná zpráva č. 072-15. Dendrochronologické datování pilotu pod základovou zdí východního křídla domu čp. 515/III v Praze na Malé Straně (Na Kampě 8), ulož. v archivu nálezových zpráv ARÚ AV ČR, Praha, v. v. i., č. j. TP-2016-694a.

- 2015a: Výzkumná zpráva č. 011-16. Dendrochronologické datování dřevěných konstrukčních prvků nalezených při archeologickém výzkumu v domě Na Kampě 8 v Praze (čp. 515/III), ulož. v archivu nálezových zpráv ARÚ AV ČR, Praha, v. v. i., č. j. TP-2016-694b.

MUK, J.-LÍBAL, D., 1963: Praha - stavebně historický průzkum, Malá Strana, blok mezi ulicemi U Lužického semináře, Cihelnou, Čertovkou a Vltavou, č. p. 515, SÚRPMO, Praha.

NOVOTNÝ, A., 1946: Zmizelá Praha 6, Grafické pohledy Prahy 1493-1850. Praha: V. Poláček.

PODLISKA, J., 2013: Nálezová zpráva - záchranný archeologický výzkum NPÚ ÚOP v hl. m. Praze 2013/02 Praha 1 - Malá Strana, Na Kampě 8, čp. 515, ulož. v archivu nálezových zpráv NPÚ ÚOP v hl. m. Praze, č. j. NPÚ-311/37406/2013.

ŠTONCNER, P., 2013: Stavebně historický průzkum, dům čp. 515 „Prachovna“, Praha 1 - Malá Strana, Na Kampě 8. Praha.

VESELÝ, J., 2015: Dům čp. 515/III u Karlova mostu - prohloubení stavebně historického průzkumu. Nepublikovaný rukopis ulož. v archivu NPÚ ÚOP v hl. m. Praze, sign. P 219.

ZAVŘEL, J., 2015: Praha 1 - Malá Strana, Kampa č. 8/515. Petrografický rozbor části pilíře Juditina mostu, ulož. v archivu nálezových zpráv ARÚ AV ČR, Praha, v. v. i., č. j. TP-2016-693.

\section{Zusammenfassung}

\section{Vorläufiger Bericht über die Ergebnisse der in Prag 1 - Na Kampě 8/515 durchgeführten Rettungsgrabung}

In den Jahren 2013-2015 wurde auf der Nordspitze der Insel Kampa eine archäologische Rettungsgrabung durchgeführt (Abb. 1). Die Grabung erfolgte an Haus Nr. 515, das an der Stelle steht, an welcher sich Pfeiler der ehemaligen Judithbrücke (1172-1342) befinden. Die erste Erwähnung dieses Hauses stammt aus dem Jahre 1516, ab dem 17. Jahrhundert taucht es dann auf Darstellungen auf (Abb. 2-5). Die Ufer der Insel waren mit einem Holzverbau befestigt, wovon wir in Raum M 13 des Nordflügels Überreste in Form von Holzrosten freigelegt haben (Abb. 6). Proben dieses Holzes wurden als nach 1569 gefälltes Eichenholz identifiziert (Kyncl 2015). Die in Raum M 16 des Nordflügels von uns entdeckte, ursprünglich schmale Inselspitze (Abb. 8) wurde im 18. Jahrhundert mit Aufschüttungen nach Osten hin erweitert. Zu Beginn des 19. Jahrhunderts wurde das Haus im klassizistischen Stil zur heutigen Form umgebaut.

Durch die archäologische Grabung wurde festgestellt, dass die klassischen tragenden Elemente - Außenmauern und Pfeiler an der Stelle, an der sich die Trennwände kreuzen - unterhalb des Grundwasserspiegels (184,84-185,20 m ü. d. M.) auf Pfählen aus Kiefernholz gegründet 
wurden. In dem sich über dem älteren Keller befindenden Abschnitt (in Sondierschnitt S 29 und in Teil M 7) stand die Außenmauer im Höhenniveau von 184,36 m ü. d. M. auf den Steinpfeilern der Judithbrücke. Die aus Mischmauerwerk bestehenden Trennwände standen auf dicht unter den Fußböden befindlichen Entlastungsbögen.

Aus der vorhergehenden barockzeitlichen Etappe sind im Nordflügel stellenweise die Fliesenfußböden erhalten geblieben, die Waschräume im Südflügel waren mit großen viereckigen Steinplatten ausgelegt, von denen Spuren im Mörtelbett übriggeblieben sind. In Raum M 8 haben wir auf zwei Höhenniveaus den zugeschütteten Raum eines verschwundenen gemauerten Kellers entdeckt, von denen sich der jüngere in einer Höhe von 186,29 m ü. d. M. und der ältere in einer Höhe von 185,18 m ü. d. M. befindet. Das älteste in den Sondierschnitten 12 und 22 sowie in Raum M 8 festgestellte Höhenniveau der Fußböden können wir zusammen mit dem westlichen Keller der ältesten Bauetappe des 16. Jahrhunderts zuordnen (Abb. 15). Das gemauerte Objekt mit Pfahlgruben in Raum M 15 und das durch Lehm verbundene Fundament in M 14b im Nordflügel lassen sich zeitlich nicht näher bestimmen, als dass sie aus dem 17. Jahrhundert stammen. Diese Bebauung diente vor allem zu wirtschaftlichen Zwecken und hing mit Handwerken zusammen, welche die Nähe zu Wasser und die Abgelegenheit der zusammenhängenden Bebauung nutzten, worauf die Freilegung von vier Gruben hindeutet (Abb. 9). Ein System von vier Gerbgruben im Innern der Gebäude diente zum Gerben von Häuten in Gerbstofflösungen. Bei einigen der Umbauten wurden die Gruben zum Lagern von gelöschtem Kalk genutzt, wie dies in Raum 17 entdeckt wurde (Abb. 10). Im Hofraum diente in älterer Zeit ein Brunnen (Abb. 7) mit einer Sandschicht zum Filtern von Sickerwasser aus der Moldau. In jüngerer Zeit wurde der Brunnen abgerissen und entlang der Mauer des Südflügels zwecks Wasserumleitung kleine Kanäle angelegt.

Im Süd- und Südwestflügel des heutigen Hauses konnten die Reste von Bauten identifiziert werden, die auf einer Planskizze aus dem Jahr 1696 abgebildet werden (Abb. 5). Dabei handelt es sich um ein rechteckiges Objekt auf dem Grundriss des Westkellers und um einen kleineren Südflügel, dem wir die Funde aus den Sondierschnitten S 2, 3, 5, 6, 23 und 27 zuordnen können. In diesen Zeitraum können wir wohl auch den Torso zweier Öfen legen, die in Sondierschnitt S 27 untersucht wurden und im 18. Jahrhundert von den Pfeilern des barocken eingewölbten Waschraums durchbrochen wurden (Abb. 11, 12). Während der Südostflügel des Hauses im Barock nach und nach vergrößert wurde, diente der Nordflügel als Mietshaus mit vielen kleinen Wohnungen, wie an den Fußböden und den erhalten gebliebenen Wänden unterhalb der aus der Zeit des klassizistischen Umbaus stammenden Aufschüttung zu sehen ist (Abb. 14, 15). Durch die an Haus Nr. 515 durchgeführte archäologische Grabung wurde die Lage des teilweise freigelegten Pfeilers der Judithbrücke unter dem südöstlichen Teil des Hauses leicht korrigiert. Im Nordteil blieb das Mauerwerk lediglich unterhalb des Wasserpegels (unter $185 \mathrm{~m}$ ü. d. M.) erhalten, im südlichen trat es erst bei 185,54 m ü. d. M. hervor, sodass sich dahinter auf dem Pfeiler mit der Strömung Schwemmschichten ablagert haben, die von mindestens zwei Hochwasserständen stammen (Zavřel 2015). Die regelmäßig bearbeiteten Sandsteinblöcke der Außenmauer waren herausgerissen, der erhaltene Kern hatte eine Länge von 10,30 m, was nur leicht über der Länge von $10 \mathrm{~m}$ liegt, die an dem am Kleinseitner Ufer des Teufelsbachs freigelegten Pfeilers gemessen wurde (Dragoun 2003, 313). Alle festgestellten Situationen waren mit Bauschutt zugeschüttet, der überwiegend neuzeitliche Keramikfragmente enthielt, eine Ausnahme bildet eine ältere, aus dem Hochmittelalter stammende Keramikscherbe. Das entspricht der Aussage der schriftlichen Quellen über die Höherlegung der Inseloberfläche durch Aufschüttungen mit Bauschutt, der von Häusern stammt, die nach Bränden abgerissenen wurden. Durch die Höherlegung sollte ein besserer Schutz vor Hochwasser erreicht werden.

PhDr. Drahomíra Frolíková, Ph.D., Archeologický ústav AV ČR, Praha, v. v. i., Letenská 4, 11801 Praha 1, Česká republika,frolikova@arup.cas.cz

Ing. arch. Jan Veselý, Národní památkový ústav, územní odborné pracoviště středních Čech v Praze, Sabinova 5, 13011 Praha 3, Česká republika,vesely.jan@npu.cz 
